14327. $-18 \mathrm{~m}$ above loc. 14326, same unit. Syringoporoid corals.

14924. $-20 \mathrm{~m}$ above loc. 14327. Limestone, medium grained, medium gray weathers same, beds $0.5-1.0 \mathrm{~m}$ thick, cliff-forming. $\mathrm{Ce}-$ rioid and fasciculate rugose corals, syringoporoid corals.

14925. - $12 \mathrm{~m}$ above loc. 14924. Limestone, medium grained, medium gray weathers same. Cerioid rugose corals.
14927. $-30 \mathrm{~m}$ above loc. 14925. Limestone, medium grained, medium gray weathers same, some chert nodules. Tabulate coral, cerioid rugose coral.

14928. $-75 \mathrm{~m}$ above loc. 14927. Limestone, medium grained, light gray weathers white, chalcedony-lined vugs numerous. Cerioid rugose corals.

\title{
STRATIGRAPHIC DISTRIBUTIONS OF GENERA AND SPECIES OF NEOGENE TO RECENT CARIBBEAN REEF CORALS
}

\author{
ANN F. BUDD, THOMAS A. STEMANN, AND KENNETH G. JOHNSON \\ Department of Geology, University of Iowa, Iowa City 52242, USA, \\ Geologisches Institut, Universität Bern, Baltzerstrasse 1, CH-3012 Bern, Switzerland, and \\ Department of Palaeontology, The Natural History Museum, Cromwell Road, \\ London SW7 5BD, United Kingdom
}

\begin{abstract}
To document evolutionary patterns in late Cenozoic Caribbean reef corals, we compiled composite stratigraphic ranges of 49 genera and 175 species using Neogene occurrences in the Cibao Valley sequence of the northern Dominican Republic and faunal lists for 24 Miocene to Recent sites across the Caribbean region. This new compilation benefits in particular from increased sampling at late Miocene to early Pleistocene sites and from increased resolution and greater taxonomic consistency provided by the use of morphometric procedures in species recognition.

Preliminary examination and quantitative analysis of origination and extinction patterns suggest that a major episode of turnover took place between 4 and $1 \mathrm{Ma}$ during Plio-Pleistocene time. During the episode, extinctions were approximately simultaneous in species of all reef-building families, except the Mussidae. Most strongly affected were the Pocilloporidae (Stylophora and Pocillopora), Agariciidae (Pavona and Gardineroseris), and free-living members of the Faviidae and Meandrinidae. At the genus level, monoand paucispecific as well as more speciose genera became regionally extinct. Many of the extinct genera live today in the IndoPacific region, and some are important components of modern eastern Pacific reefs. Global extinctions were concentrated in freeliving genera. During the turnover episode, no new genera or higher taxa arose. Instead, new species originated within the surviving Caribbean genera at approximately the same time as the extinctions, including many dominant modern Caribbean reef-building corals (e.g., Acropora palmata and the Montastraea annularis complex).

Excluding this episode, the taxonomic composition of the Caribbean reef-coral fauna remained relatively unchanged during the Neogene. Minor exceptions include: 1) high originations in the Agariciidae and free-living corals during late Miocene time; and 2) regional or global extinctions of several important Oligocene Caribbean reef builders during early to middle Miocene time.
\end{abstract}

\section{INTRODUCTION}

$\mathbf{R}$ ECENTLY PUBLISHED and ongoing studies of the systematics of the Neogene reef-coral fauna of the northern Dominican Republic (Foster, 1986, 1987; Budd, 1991; Stemann, 1991) have resulted in significant modifications to previously reported stratigraphic distributions of many Caribbean reef corals (e.g., Vaughan, 1919; Frost, 1977), especially at the species level. The modifications stem primarily from two factors: 1) more refined methods of species recognition; and 2) new Pliocene occurrences of taxa that were previously unknown or regarded as exclusively pre-Pliocene [e.g., Acropora saludensis, Siderastrea silicensis, Goniopora calhounensis, Montastraea canalis, $\mathrm{M}$. trinitatis, $\mathrm{Pa}$ vona (Pseudocolumnastrea) spp., among others]. Of the two factors, the first is by far more important. Larger sample sizes, sampling at close intervals within a stratigraphic framework, and excellent preservation of the Dominican Republic fauna have, for the first time, permitted use of multivariate statistical procedures to discriminate morphospecies. This has improved resolution and consistency in distinguishing morphologically similar species. As a consequence, many species that were overly subdivided by early workers such as Vaughan (1919), Vaughan and Hoffmeister $(1925,1926)$, and Weisbord $(1971,1973,1974)$ have been synonymized; many other species that were lumped by more recent workers such as Frost (1977) have been teased apart (see discussion in Foster, 1986, and Budd, 1991).

Since data on these newly revised stratigraphic ranges are scattered throughout a number of published and unpublished accounts, our purpose in the present paper is to synthesize all existing information on the entire Caribbean reef-coral fauna so that it can be readily available, especially to paleontologists and evolutionary ecologists analyzing evolutionary patterns. Such information is essential for evaluating extinction and origination patterns in tropical reef biotas over the past 20 m.y. and for assessing reef community reorganization associated with Neogene to Recent climatic perturbations. In the present paper, we present a preliminary comparison of species-level extinction and origination rates within and among families as part of our documentation of stratigraphic ranges. In this comparison, we show that evolutionary rates were accelerated during Plio-Pleistocene time, and that times of acceleration differ little among families. We also briefly explore evolutionary patterns in genera and show that many of the genera that became extinct in the Caribbean still survive today in the Indo-Pacific. Some even dominate modern eastern Pacific reefs, suggesting that the dispersal hypothesis for the origin of the eastern Pacific fauna may be oversimplified. In later papers, we plan to use the data presented 
TABLE 1-Occurrences of species of reef corals in the Neogene of the northern Dominican Republic. Numbers $\leq 15$ within each river section refer to Neogene nannoplankton zones indicated on stratigraphic sections by Saunders et al. (1986); 25 refers to Paleogene Zone NP25. Numbers for each species correspond with those given in Appendix I.

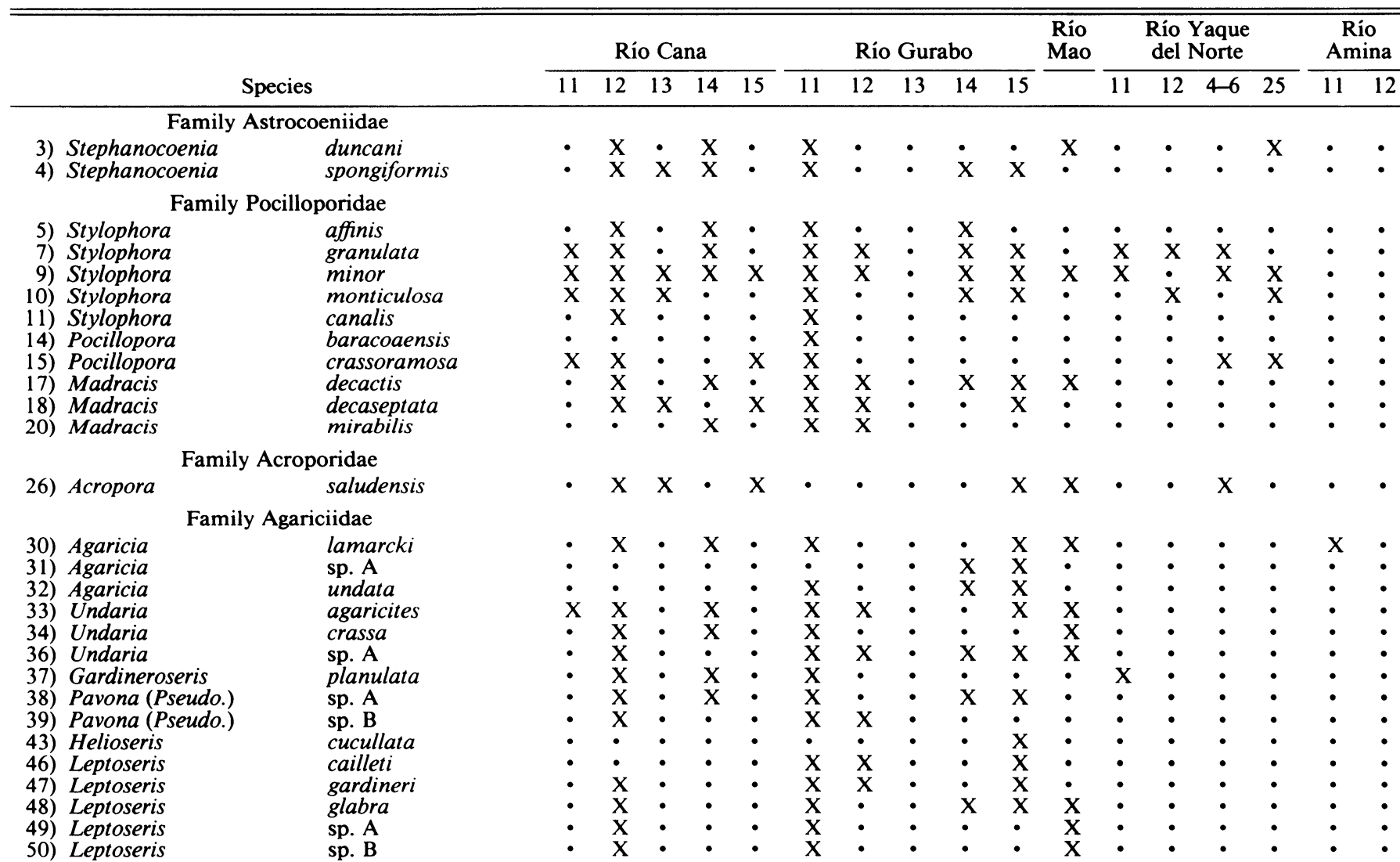

Family Siderastreidae

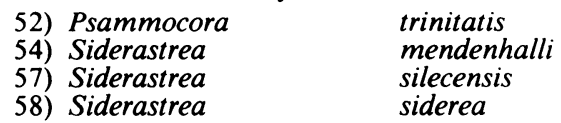

Family Poritidae
64) Porites-I
65) Porites-I
68) Porites-I
69) Porites-II
70) Porites-II
78) Goniopora
79) Goniopora
80) Goniopora
82) Alveopora

macdonaldi
portoricensis
waylandi
baracoaensis
convivatoris
calhounensis
hilli
imperatoris
tampae

Family Faviidae

83) Cladocora

87) Favia

91) Favia

98) Diploria

99) Diploria

102) Manicina (Man.)

103) Manicina (Teleio.)

104) Manicina (Teleio.)

105) Manicina (Teleio.)

106) Manicina (Teleio.)

107) Manicina (Teleio.)

108) Manicina (Teleio.)

110) Thysanus

111) Thysanus

112) Colpophyllia

114) Colpophyllia

119) Montastraea-I

121) Montastraea-I

123) Montastraea-

sp. A
dominicensis
sp. A
sp. A
sp. B
puntagordensis
grandis
navicula
sp. A
sp. B
sp. C
sp. D
excentricus
floridanus
amaranthus
natans
brevis
limbata
trinitatis




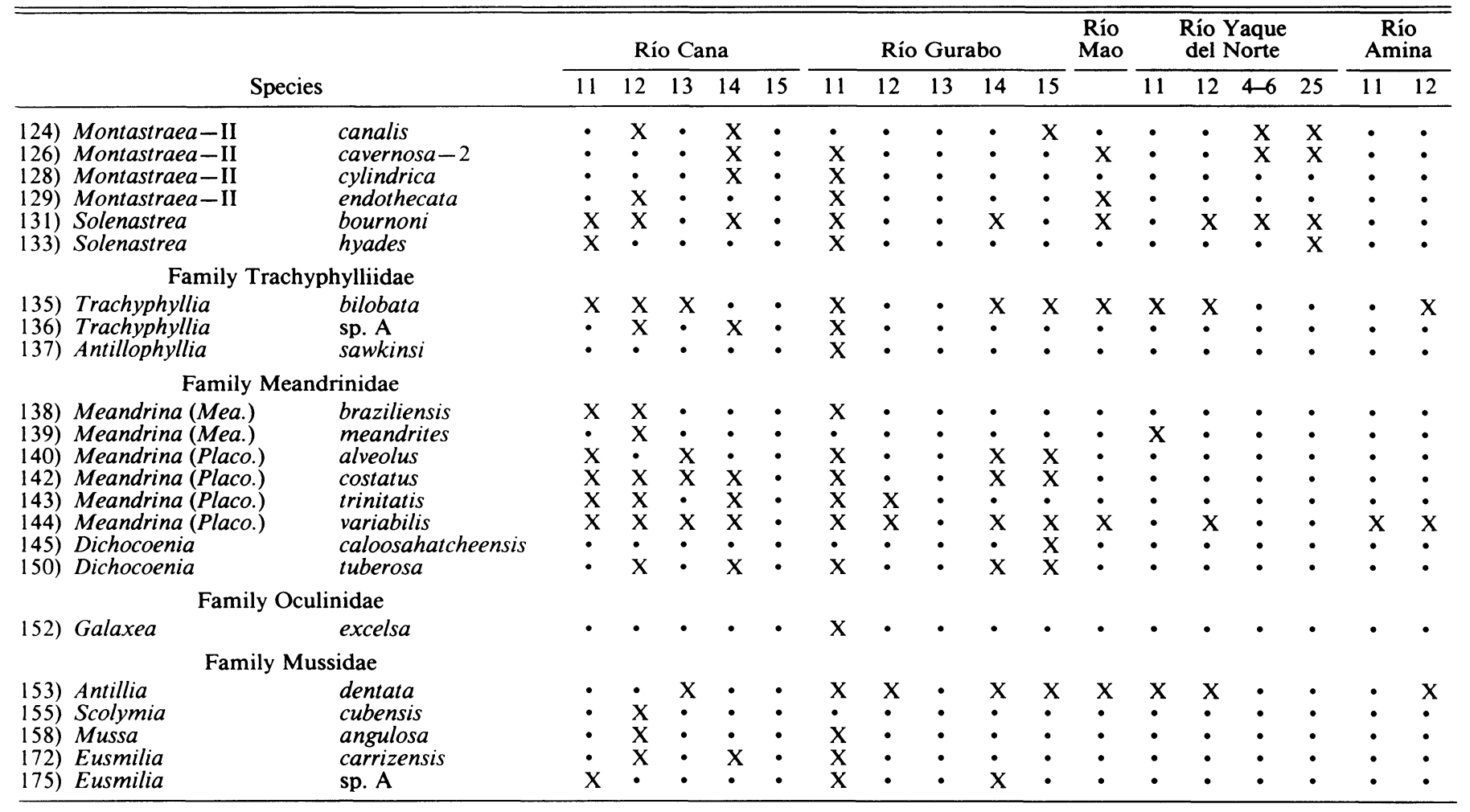

here: 1) quantitatively to analyze a major turnover episode in the fauna during Plio-Pleistocene time (Budd et al., 1994); and 2) to examine the role of ecological factors in determining susceptibility to extinction. Eventually, we hope the data can be used to develop a biostratigraphic framework useful to marine geologists and sedimentologists in age dating Neogene reef sequences.

One important aim in our present summary is to document explicitly the criteria used to discriminate taxa, to assign ages to occurrences, and to estimate composite stratigraphic ranges. Outlining these criteria should facilitate future modifications and additions to the present compilation as more faunas are studied, higher resolution age dates become available, and methods of species recognition are further refined. Outlining these criteria will also permit a rigorous evaluation of sample bias, essential to subsequent quantitative analysis of evolutionary patterns (Koch and Morgan, 1988). Because of numerous sampling irregularities, we do not provide confidence intervals on our stratigraphic ranges (e.g., as suggested by Marshall, 1990). We believe that, as in other macrofossil occurrence data derived from samples not taken in bulk, our data violate many assumptions of such methods.

\section{MATERIAL}

The compilation consists of occurrences of 175 species of Caribbean reef corals from early Miocene to Recent time, and contains all recorded hermatypic taxa except the families Oculinidae and Rhizangiidae. The latter two families were excluded because their species only questionably or variably contain zooxanthellae and therefore are not important reef builders. The one exception is the inclusion of the large massive reef builder Galaxea in the family Oculinidae.

The data were derived from: 1) material in Neogene sections along five rivers in the northern Dominican Republic (Table 1), which was collected by J. Geister, P. Jung, and J. B. Saunders (Saunders et al., 1986); and 2) 22 faunal lists from early Miocene to Pleistocene sites scattered across the Caribbean (Tables 2, 3). These data include all published Miocene to Pleistocene Caribbean material. Occurrences in the Recent Caribbean were obtained from a faunal list for the north coast of Jamaica (Wells and Lang, 1973). The Jamaican list was selected because of the location in a high-diversity area, generally regarded as representative of the modern species composition of the entire $\mathrm{Ca}$ ribbean. Because of similarities between some of the Neogene Dominican Republic fauna and modern Brazilian taxa, occurrences in Brazil (Laborel, 1969) have also been noted in the compilation. With the possible exception of Brazil, endemic species currently are believed to be rare in the Caribbean today (Liddell and Ohlhorst, 1988). Together the localities include both carbonate and siliciclastic sequences deposited in a range of nearshore to deeper forereef environments (Table 2).

Absolute age dates for the northern Dominican Republic occurrences were estimated by comparing nannofossil zones indicated on the stratigraphic sections and text in Saunders et al. (1986) with the Neogene Time Scale of Berggren et al. (1985). Age dates for the 22 published faunal lists were taken from the most up-to-date available published information (Table 2). Because of uncertainties in these dates, especially in many of the 22 faunal lists, overly long time intervals (mean locality duration $=2.8 \mathrm{~m}$.y.) have been assigned to many localities, even though the deposits most likely accumulated over short periods of time. The compilation is based on an uneven distribution of localities in geologic time, with large numbers of localities at 8-6 Ma and at 3-1 Ma. Furthermore, corals in some localities were much more intensively sampled than in others. Except in the northern Dominican Republic, first and last occurrences of species lie 


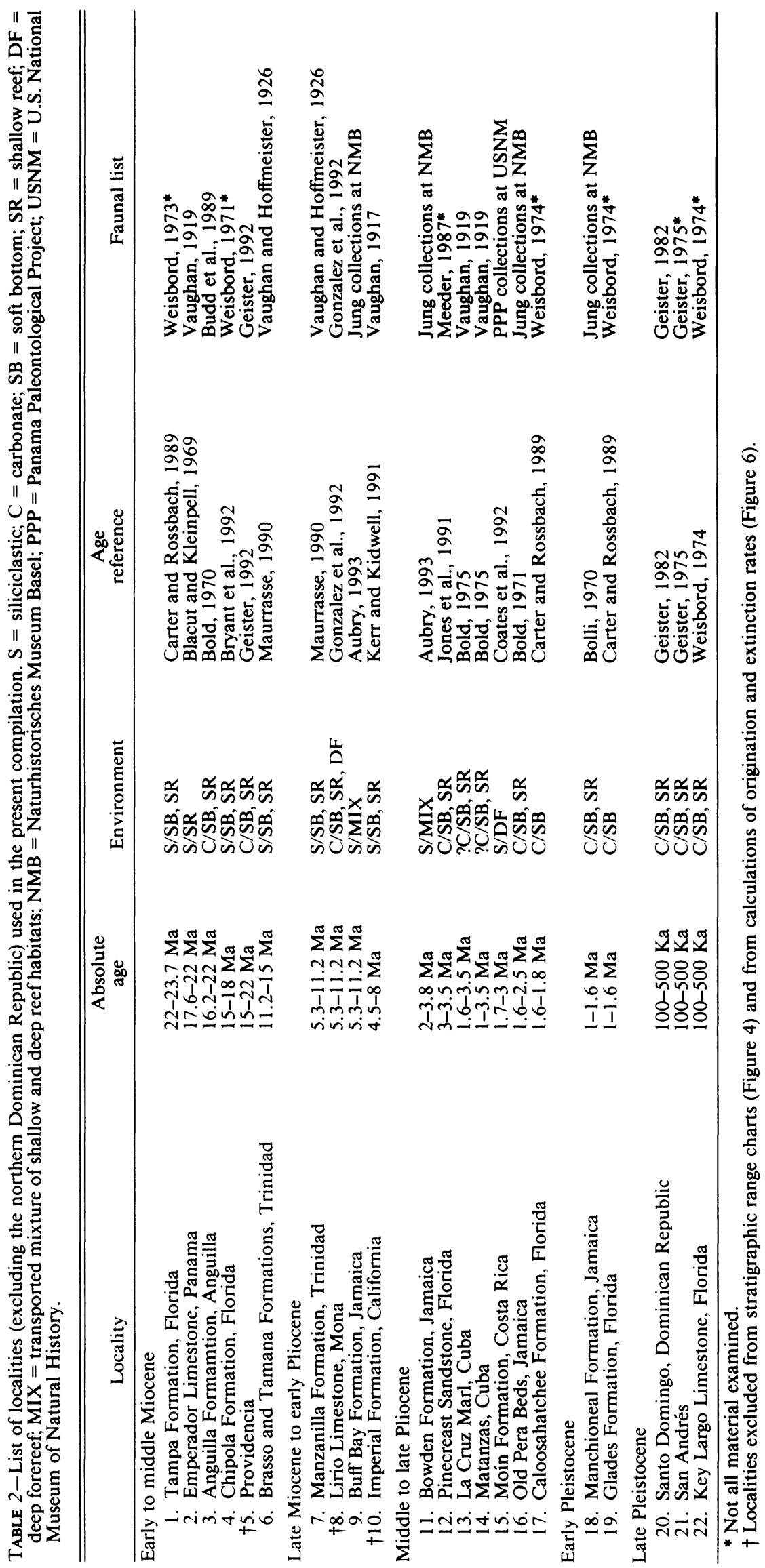


between and not within sequences. These sampling biases need to be considered in subsequent analyses of evolutionary patterns.

\section{METHODS}

Species recognition. - The diagnostic morphologic characters used in routine specimen identification (Table 4) were derived primarily through morphometric study of the reef corals collected in the Dominican Republic (Foster, 1986, 1987; Budd, 1991; Stemann, 1991). The procedures in the morphometric analyses involved first sorting all collected Neogene material into families and genera, regardless of stratigraphic position, using diagnostic criteria (Appendix) derived from Vaughan and Wells (1943) and Wells (1956), and modified following Veron et al. (1977) and Veron and Pichon (1979). Representatives of each of the important genera in the Dominican Republic collection are illustrated in Figures 1-3. Preliminary phylogenetic study of the genera suggests that some previously described genera are similar enough morphologically to warrant treatment only as subgenera of one genus and not as separate genera (i.e., Manicina and Teleiophyllia; Meandrina and Placocyathus). Others contain evolutionary subunits, distinct enough to form subgenera [i.e., species of Porites with widely spaced corallites (I) vs. those with closely spaced corallites (II), and species of Montastraea with approximately 24 septa per corallite (I) vs. those with 30 or more septa per corallite (II)]. The details of these taxonomic problems will be outlined separately in later systematic publications. In the present compilation, genera and subgenera have been modified to correct for inconsistencies.

After the collections were sorted, a unique set of five to twelve quantitative characters, including both linear measures and counts made on calicular surfaces or in thin section, were assembled for each genus. These characters were selected to include all features traditionally used to distinguish species within each genus, as outlined in Vaughan (1919). Where possible, the characters were measured on five to ten corallites per colony. Colony means were analyzed using principal component analysis, average linkage cluster analysis, and canonical discriminant analysis to recognize discrete groups of colonies separated from one another by morphologic gaps. Type specimens from many of the 22 faunal lists in the compilation were subsequently measured and analyzed using similar multivariate statistical techniques to determine the degree of similarity with the Dominican Republic morphospecies. On the basis of the results, names were designated for the Dominican Republic morphospecies following established rules of taxonomic nomenclature. The details of these procedures, as well as resampling methods applied in the implementation of multivariate statistical procedures, are described in Budd (1991) and Budd and Coates (1992). At least for Porites (Potts et al., 1993) and Montastraea (Knowlton et al., 1992; Budd, 1993), living species recognized using similar morphometric methods generally correspond with those recognized using molecular data.

The results of these morphometric procedures include the synonymy of many species separated by early workers such as Vaughan (1919), Vaughan and Hoffmeister (1925, 1926), and Weisbord (1971, 1973, 1974), and the teasing apart of species previously synonymized by Frost (1977). For example, in the Poritidae (Foster, 1986), 13 species (eight in Porites and five in Goniopora) described by the first three sets of authors were synonymized, yielding a total of six species (four in Porites and two in Goniopora); conversely, in contrast to four species listed by Frost (1977), a total of eight species (five Porites and three Goniopora) were recognized in the upper Miocene and lower Pliocene of the Dominican Republic. Similarly, in Montastraea and Solenastrea, three previously described species of Montas- traea and two species of Solenastrea were synonymized, yielding a total of seven species of Montastraea and two species of Solenastrea in the upper Miocene and lower Pliocene of the Dominican Republic (Budd, 1991). In contrast, Frost (1977) listed only three species of Montastraea, but two species of Solenastrea. In addition to these taxonomic modifications, the morphometric analyses also detected new species, many of which remain undescribed to date. These new species will be described as part of more extensive systematic monographs that form part of the "Neogene Paleontology of the Northern Dominican Republic" series. We refer here to these new species with letters.

Based on the results of morphometric analyses, three or more diagnostic characters were selected for use in routine species identification within each genus (Table 4). These characters were used to identify species in unidentified collections in the present compilation [e.g., the Jung collections at the Naturhistorisches Museum Basel (NMB) and the Panama Paleontological Project (PPP) collections at the U.S. National Museum (USNM)]. Together with the morphometric data, they were also used to evaluate the validity of species in the faunal lists (Table 3) and to modify these lists (Appendix). Original specimens were actually examined in most cases; in the few instances where this was not possible (Table 2), published photographs and systematic descriptions were used.

Composite stratigraphic ranges. - Stratigraphic ranges (Figure 4) were estimated at the species level using first and last occurrences for each of the 175 species included in the compilation (Tables 1, 3). The estimates were derived using maxima for the absolute age dates for each locality, as shown in Table 2. Occurrences at three localities (Table 2) for which age determinations are highly speculative or which lie in geographically remote areas were not included in the data set. Taxa occurring in only one locality (species $6,71,86,93,96,122,132,147$, 164 listed in the Appendix) were also not included. This information, together with data presented in Budd et al. (1992), was used to estimate total stratigraphic ranges for Neogene to Recent genera in the Caribbean region (Figure 5).

Comparisons of extinction and origination rates among families. - Differences in evolution among families were studied by quantitatively examining patterns of origination and extinction (Figure 6). To calculate these rates, the past 22 million years were subdivided into $2 \mathrm{~m}$.y. time intervals, and numbers of first and last occurrences and species richness were estimated for each interval (Table 5). Estimates of species richness were made using the range-through method, in which species are counted within a given time interval based on earlier and later occurrences, even if they were not actually encountered during that particular interval. Because of uncertainties in age determinations for some localities, estimates of numbers of originations and extinctions were made by weighting first and last occurrences relative to the time duration assigned to the site in which they took place (methods modified after Barry et al., 1990). Estimated numbers of originations and extinctions were then divided by species richness to calculate evolutionary rates and compare temporal trends among families (Figure 6). Originations in localities on a boundary between time intervals were assigned to the lower interval. Calculations were made for only the seven families containing more than 10 species over the entire time period (as listed in Table 5 and Figure 6).

\section{RESULTS}

Qualitative examination of species-level patterns. - Stratigraphic range charts (Figures 4,5 ) and plots of extinction and origination rates (Figure 6) reveal accelerated rates of extinction between 4 and $1 \mathrm{Ma}$ in all seven of the major families except the Mussidae. Origination rates were equally high at the same 


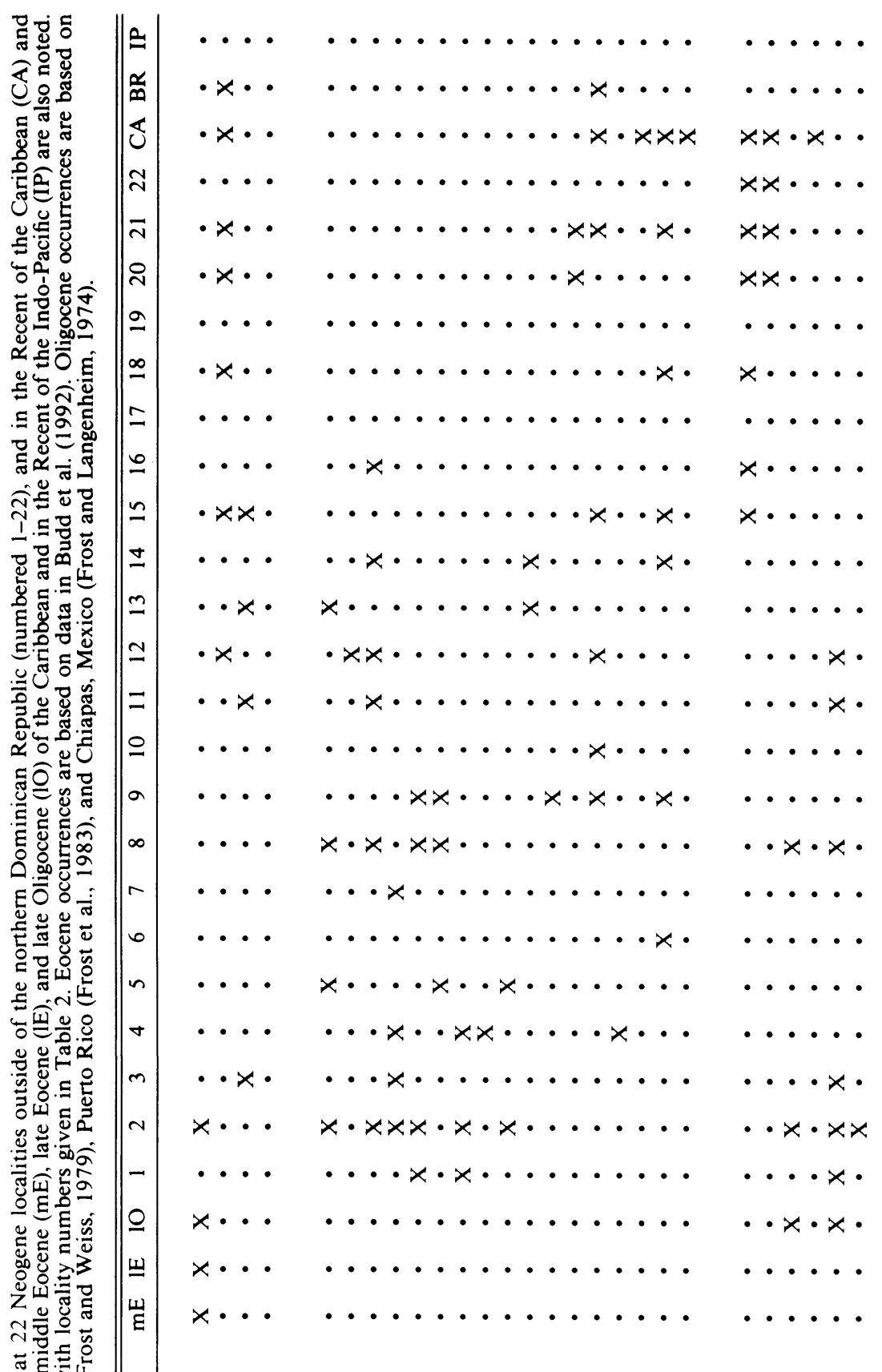

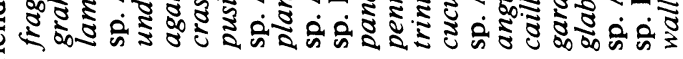
学 高 
...........

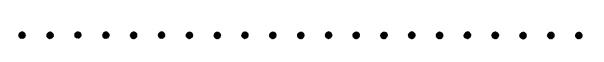

$\ldots \ldots \ldots \ldots \ldots \ldots$

$\cdots \cdot x \cdot x \cdot \cdots$

$\cdot x \cdots \cdot x \cdot x \cdots \cdots \cdots \cdots$

$\cdot x \cdot \cdots \times \cdot \cdots \cdot x x \cdot x \cdot \cdot x x \cdot \cdot$

$\cdots \cdot x \cdot x \cdot \cdots$

$\cdot x \cdots \cdots \cdot x \cdot x \cdot x \times x \cdot \cdots \cdot$

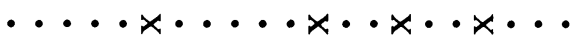

... $\times \cdot x \cdot \cdots$

$\cdot x \cdots \cdots \cdots+\cdots \times x \cdot \cdots$

$\cdots \cdots \cdot \ldots \cdot \cdots x x \cdot x \cdot \cdot x \cdot \cdots$

-........

$\cdot x \cdots \ldots \ldots+\cdots \times x+\cdots$

$\ldots \ldots \times \cdots \cdots \times x \cdot x \cdots \ldots$

$\cdots \times x \cdot x \cdot \cdots$

...............

$\times \ldots \ldots \ldots \ldots \ldots \ldots$

... $x \cdot x \cdot \cdots$

. $\ldots \ldots \ldots \ldots \ldots \times \ldots \ldots$

......... $x \cdot x \times \cdot \cdot x \cdots$

- $\cdot x \cdot x \cdot \cdots$

................

$\cdots x \cdot \ldots \cdot \cdots \cdot x \cdot \cdot x \cdot \cdot x \cdot x \cdot$

.........

.................

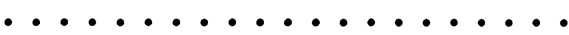

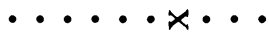

$\cdot x \cdot x \cdot \cdot x \cdot x \cdot \cdots \cdot x \cdot \ldots \cdot \cdot$

$x \cdots \cdots \times \cdots \cdots \cdots \cdot x \cdot$

$\cdots \cdots \cdots$

.....................

$\cdot x \cdot \ldots \ldots \ldots \ldots \cdot x \cdot \ldots$

$\cdots \times \times \times x \cdots$

$\cdot x \cdot \cdots \cdot x \cdot \cdots \cdot x x \cdot \cdot x \cdot \cdot$

$\cdots \cdots \times \cdot \cdots$

$\ldots \ldots \ldots \ldots \ldots \ldots \ldots$

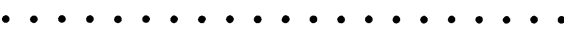

....x $\ldots \cdot \cdot x \cdot x x \cdot \cdot x \cdot x \cdot$

. $\times \cdots \cdots \cdot$

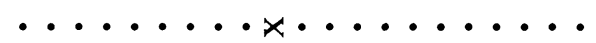

$\ldots \ldots \ldots \ldots \ldots \ldots$

........

...............

$\ldots \ldots \ldots \ldots \ldots$

........

...x $x \times x \cdots \ldots \ldots \ldots$

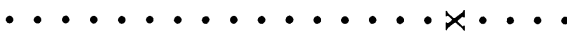

$x \cdots \ldots \ldots \times \ldots \ldots$

$\times \cdots \cdots \cdots$

$\cdots \times \cdot \cdot x \cdot \cdot$

$x x \cdots \cdot \cdot x x$

$\ldots \ldots \times x \cdots \ldots \ldots \ldots$

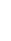

$\cdot x \cdot \cdots \cdot \cdot x \cdot$

$x \cdot x \times \cdot \cdot x \times \cdots \cdots \cdot \ldots x \cdot \cdots$

$x \cdot x x \cdots x x \cdots \cdots \cdot \cdots x x x \cdot$

....x...

$\cdots \times \cdot x \cdot \cdots \cdots \cdot \times x \times x$

..............

$\cdot x \cdot \cdots \cdot x x$

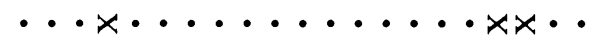

$x \ldots \ldots \ldots \ldots \ldots \ldots$

$\cdots \cdots \cdots$

$\cdots$

.................

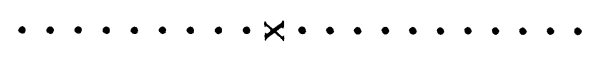

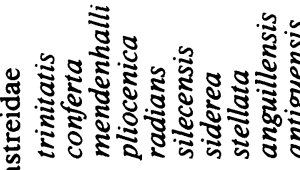

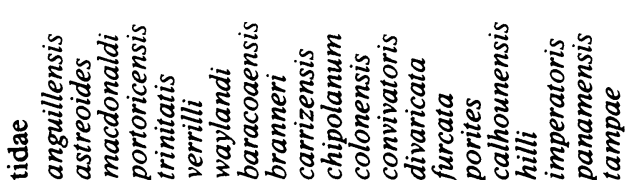

:

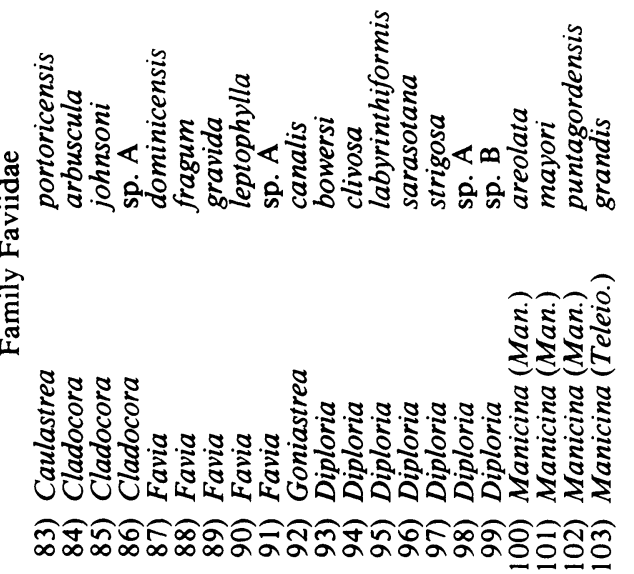




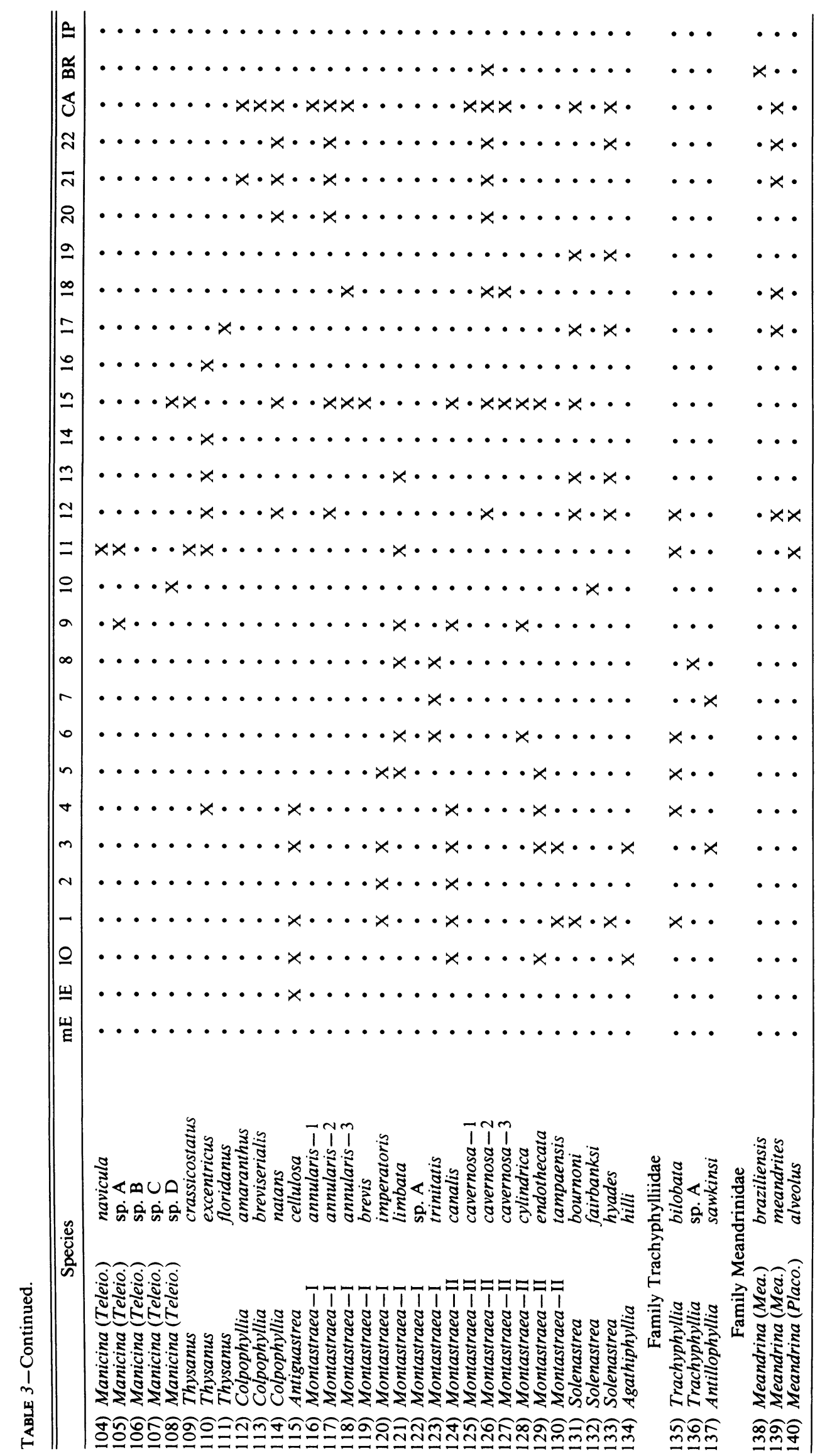




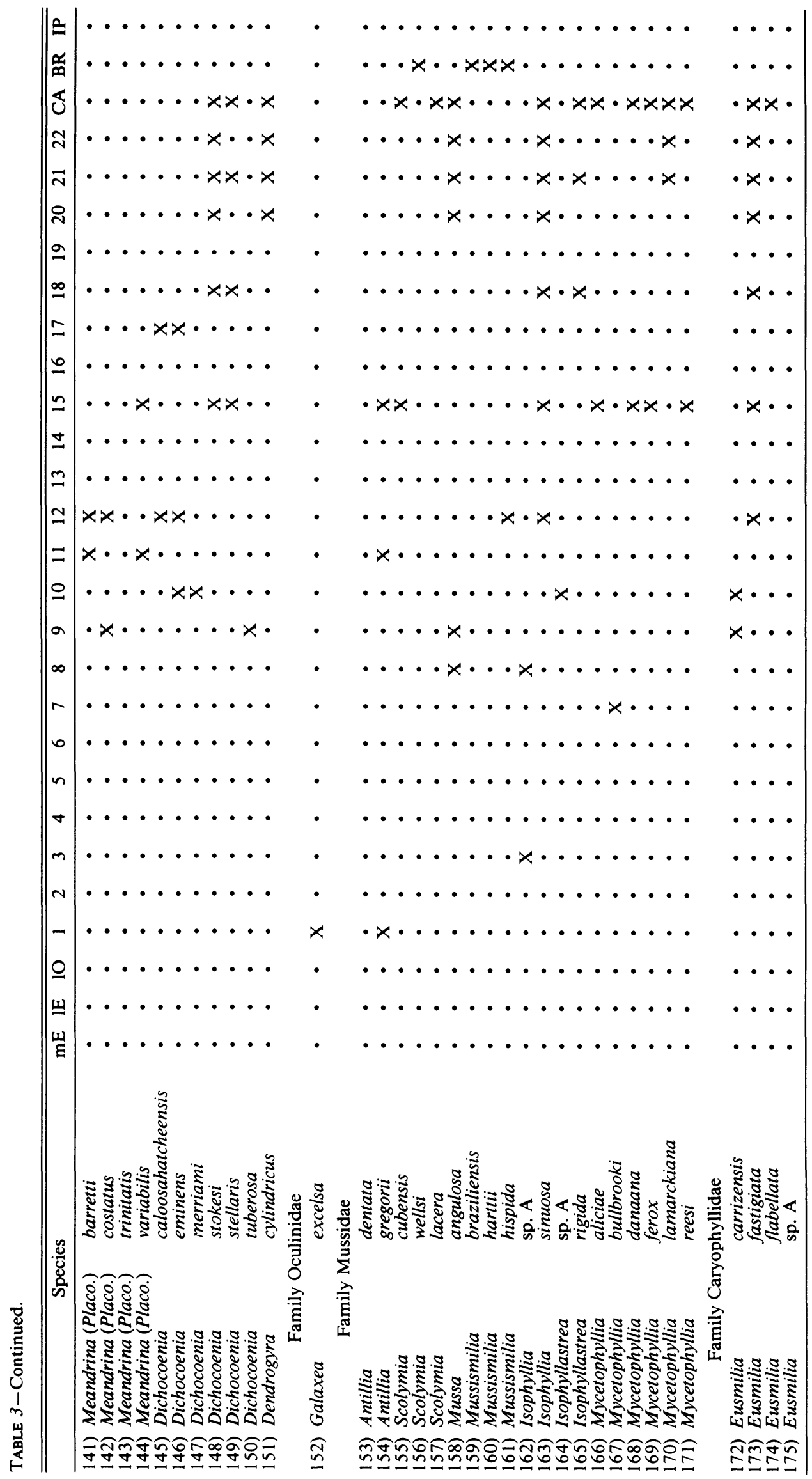


time in all families except the Agariciidae. Nevertheless, on close examination of range charts, subtle differences in both timing and magnitude can be detected among families, especially with respect to origination. In the families Astrocoeniidae, Pocilloporidae, and Acroporidae (Figure 4), high numbers of extinctions occurred between approximately 4 and 1 Ma during the Plio-Pleistocene and between 18 and $15 \mathrm{Ma}$ during the early to middle Miocene. In the later episode, the genera Stylophora (four species) and Pocillopora (three species) were affected most heavily, resulting in the extinction of both genera in the Caribbean. However, as indicated in Figure 5, Pocillopora remains common today in the eastern Pacific; both genera are abundant elsewhere in the Indo-Pacific (Glynn and Wellington, 1983; Budd, 1989; Veron, 1986). In the earlier Miocene episode, two genera with only one Caribbean species, Astrocoenia and Astreopora, both became extinct in the Caribbean region. Although Astrocoenia became globally extinct, Astreopora remains common today in the Indo-Pacific (Veron, 1986). Post-Miocene Caribbean originations in the three families occurred largely in two genera, Acropora (three species) and Madracis (three species).

In the Agariciidae (Figure 4), large numbers of species originated between 11 and $6 \mathrm{Ma}$ during the late Miocene, while extinctions were concentrated during the early Pliocene (5-3 Ma). Nevertheless, five species survived the period of Plio-Pleistocene turnover. The genera Pavona, Gardineroseris, and Leptoseris experienced the highest numbers of extinctions of species, resulting in the extinction of Pavona (four species) and Gardineroseris (one species) from the Caribbean region. However, as in Pocillopora (Figure 5), these two genera remain common today in the eastern Pacific (Glynn and Wellington, 1983; Budd, 1989) and elsewhere in the Indo-Pacific (Veron, 1986). By contrast, late Miocene originations were rare in the Siderastreidae (Figure 4). Notable in the siderastreids is the extinction of the single Neogene Caribbean species of Psammocora from the $\mathrm{Ca}$ ribbean region at the end of the Miocene. The genus lives today in the eastern Pacific and elsewhere in the Indo-Pacific (Glynn and Wellington, 1983; Budd, 1989; Veron, 1986). Like Astrocoenia, the siderastreid genus Pironastrea (two species) became globally extinct during the early to middle Miocene.

In the Poritidae (Figure 4), extinctions and originations were concentrated between 4 and 1 Ma during Plio-Pleistocene time, with species originating only in Porites (seven species). The genus Goniopora (three species) became extinct in the Caribbean during this time. The single remaining Caribbean species of Alveopora went extinct during the earliest Miocene. Both Goniopora and Alveopora survive today in the Indo-Pacific.

In the Faviidae (Figure 4), relatively large numbers of freeliving species (Manicina, Teleiophyllia, Thysanus) and more massive meandroid species (Diploria) originated between 11 and $6 \mathrm{Ma}$ during the late Miocene. However, as in the agariciids, which also radiated at that time, extinctions in many of these taxa were concentrated between 4 and $1 \mathrm{Ma}$, resulting in the complete extinction of the subgenus Teleiophyllia (five species) and the genus Thysanus (three species). As in Porites, extinctions and possible originations were common in Montastraea between 4 and $1 \mathrm{Ma}$. Three faviid genera with only one Neogene Caribbean species (Goniastrea, Antiguastrea, and Agathiphyllia) suffered early to middle Miocene extinctions. In contrast to other faviids, members of the genus Solenastrea (two species) were strikingly long lived. In the closely related free-living trachyphylliids (Figure 4), extinctions were staggered over the late Miocene to late Pliocene, and originations were rare.

Seven species originated in the meandrinids between 11 and $6 \mathrm{Ma}$ during the late Miocene (Figure 4), and most involved free-living species of the subgenus Placocyathus. Four species also originated in the attached massive genus Dichocoenia between 5 and $3 \mathrm{Ma}$ during the early to middle Pliocene. Extinctions of genera and subgenera were concentrated between 4 and 1 Ma during the Plio-Pleistocene. Between the early to middle Pliocene and today, Meandrina braziliensis became geographically restricted to Brazil. The genus Galaxea (Oculinidae) followed an evolutionary pattern more similar to that of Psammocora (Figure 4), characterized by only one Miocene Caribbean species, Caribbean extinction during the late Miocene, and occurrences today in the Indo-Pacific (Veron, 1986).

The Mussidae and Eusmilia (Caryophyllidae) differ considerably from the other groups by exhibiting a large radiation between 4 and $1 \mathrm{Ma}$, accompanied by few extinctions, and resulting in a relatively high number of extant species (Figure 4). As in the agariciids and free-living faviids and meandrinids, other originations in these two groups were concentrated between 11 and $6 \mathrm{Ma}$ during the late Miocene. Like Meandrina braziliensis, the genus Mussismilia became geographically restricted to Brazil.

Quantitative analysis of species-level patterns. - Comparison of plots of extinction and origination rates for each family (Figure 6) shows that the mussids had the highest rates of origination (>20 percent per $2 \mathrm{~m} . \mathrm{y}$.) over the past $6 \mathrm{~m} . \mathrm{y}$., resulting in a steady increase in richness in the family since the late Miocene. Similarly high rates of origination were achieved in the siderastreids between 6 and $4 \mathrm{Ma}$, and in the pocilloporids over the past $2 \mathrm{~m}$.y. In general, however, species richness declined slightly among the siderastreids since the middle Miocene, and among the pocilloporids since the early Pliocene (Table 5). New species of Madracis were responsible for the accelerated post-Pliocene origination rates in the pocilloporids. Moderately high origination rates (10-20 percent per 2 m.y.) prevailed in the agariciids throughout the Miocene (i.e., 22-6 Ma), in the faviids between 8 and $4 \mathrm{Ma}$, and in the meandrinids between 10 and $4 \mathrm{Ma}$. Increases in numbers of free-living corals most likely played a major role in the faviid and meandrinid originations. The pocilloporids had the lowest overall rates of origination $(<10$ percent per 2 m.y.) over the last 22 m.y.

Chi-square statistical tests confirm that rates of extinction differed little among families (Figure 6) (e.g., at 6-4 Ma, chisquare for origination $=6.78$, d.f. $=6, P>0.25$, chi-square for

FIGURE 1-Common genera of reef corals collected in the Neogene sequence of the northern Dominican Republic. Calical surfaces. 1, Stephanocoenia spongiformis, NMB D5763, upper Miocene, NMB loc. 15847, ×5. 2, Stylophora monticulosa, NMB D6007, upper Miocene, NMB loc. 16883, $\times 10.3$, Pocillopora crassoramosa, NMB D6008, upper Miocene, NMB loc. 16934, × 10. 4, Madracis decaseptata, NMB D6009, upper Miocene, NMB loc. 15846, $\times 10.5$, Acropora saludensis, NMB D6015, upper Miocene, NMB loc. 16855, $\times 5.6$, Agaricia sp. A, NMB D5932, lower Pliocene, NMB loc. 15822, ×5. 7, Undaria crassa, NMB D5997, upper Miocene, NMB loc. 15858, $\times 5.8$, Gardineroseris planulata, NMB D5943, lower Pliocene, NMB loc. 16818, $\times 5$. 9, Pavona (Pseudocolumnastrea) sp. A, NMB D5943, upper Miocene, Arroyo Bellaco, $\times 5$. 10, Leptoseris gardineri, NMB D5945, upper Miocene, NMB loc. $15855, \times 5$. 11, Psammocora trinitatis, NMB D6016, lower Miocene, NMB loc. 16943, ×5. 12, Siderastrea silecensis, USNM 88302, lower Pliocene, Tulane loc. $1363, \times 5$. 

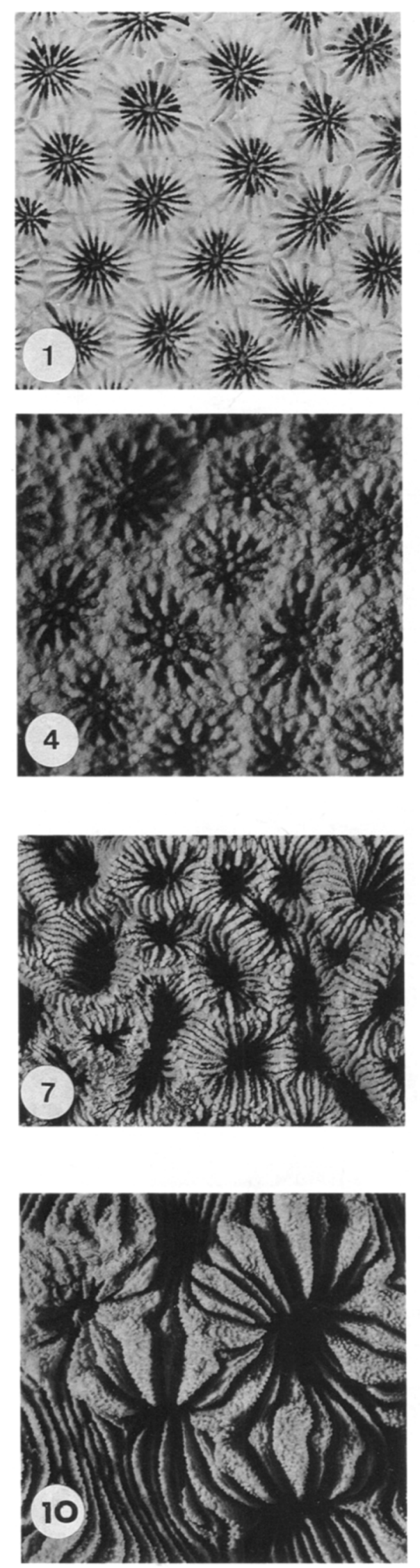
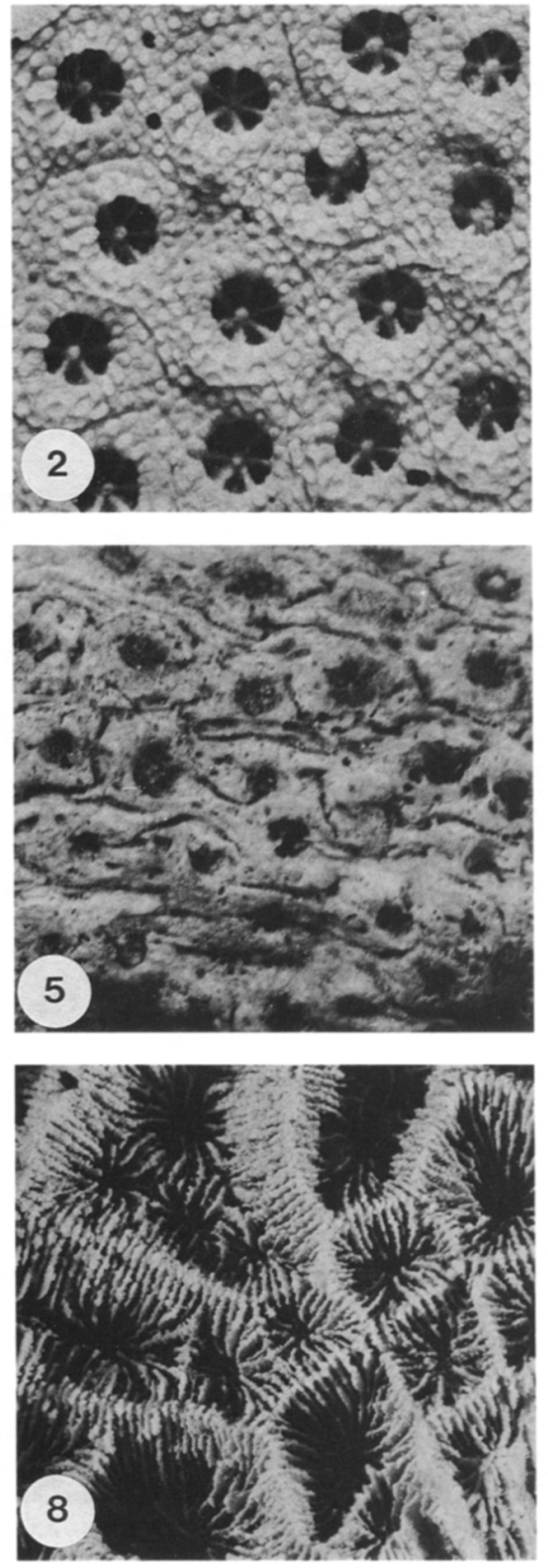

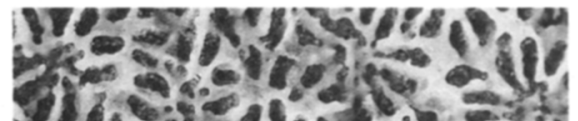

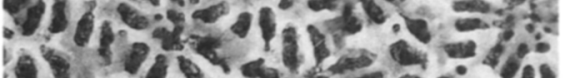

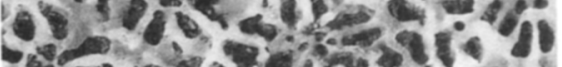

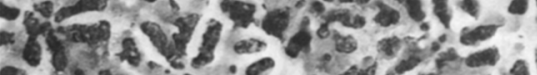

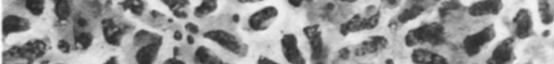

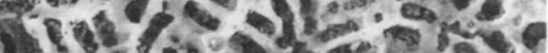
a $18=00$ a d :

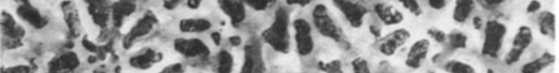

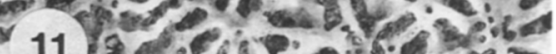

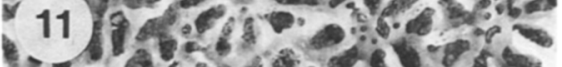

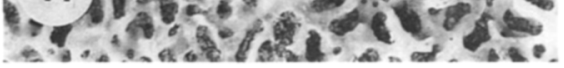
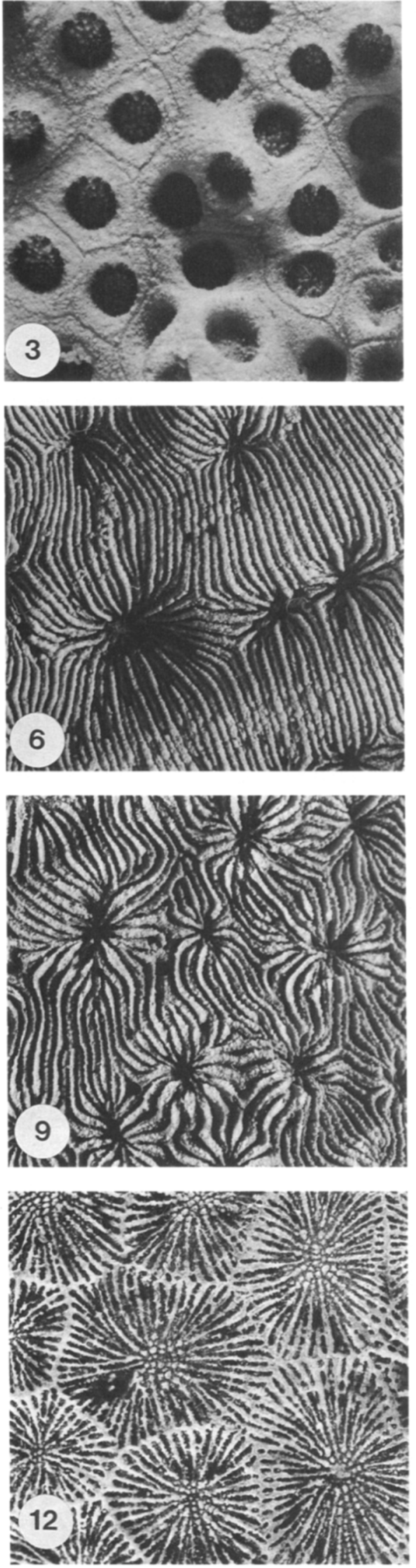

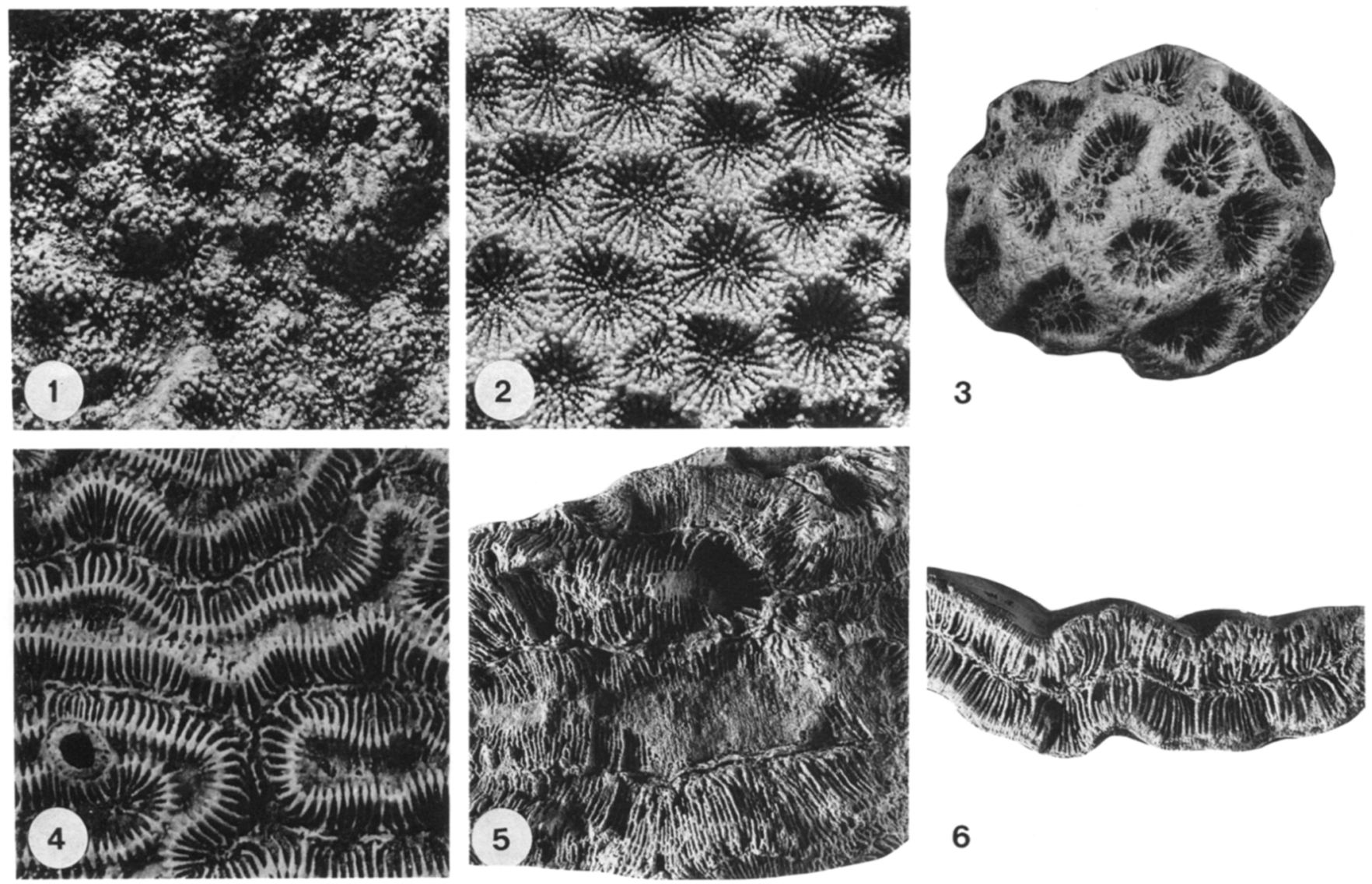

6

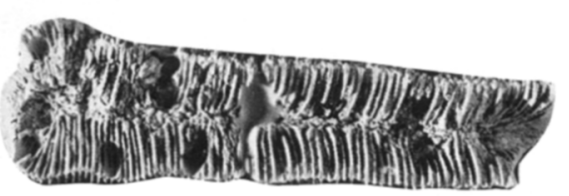

7
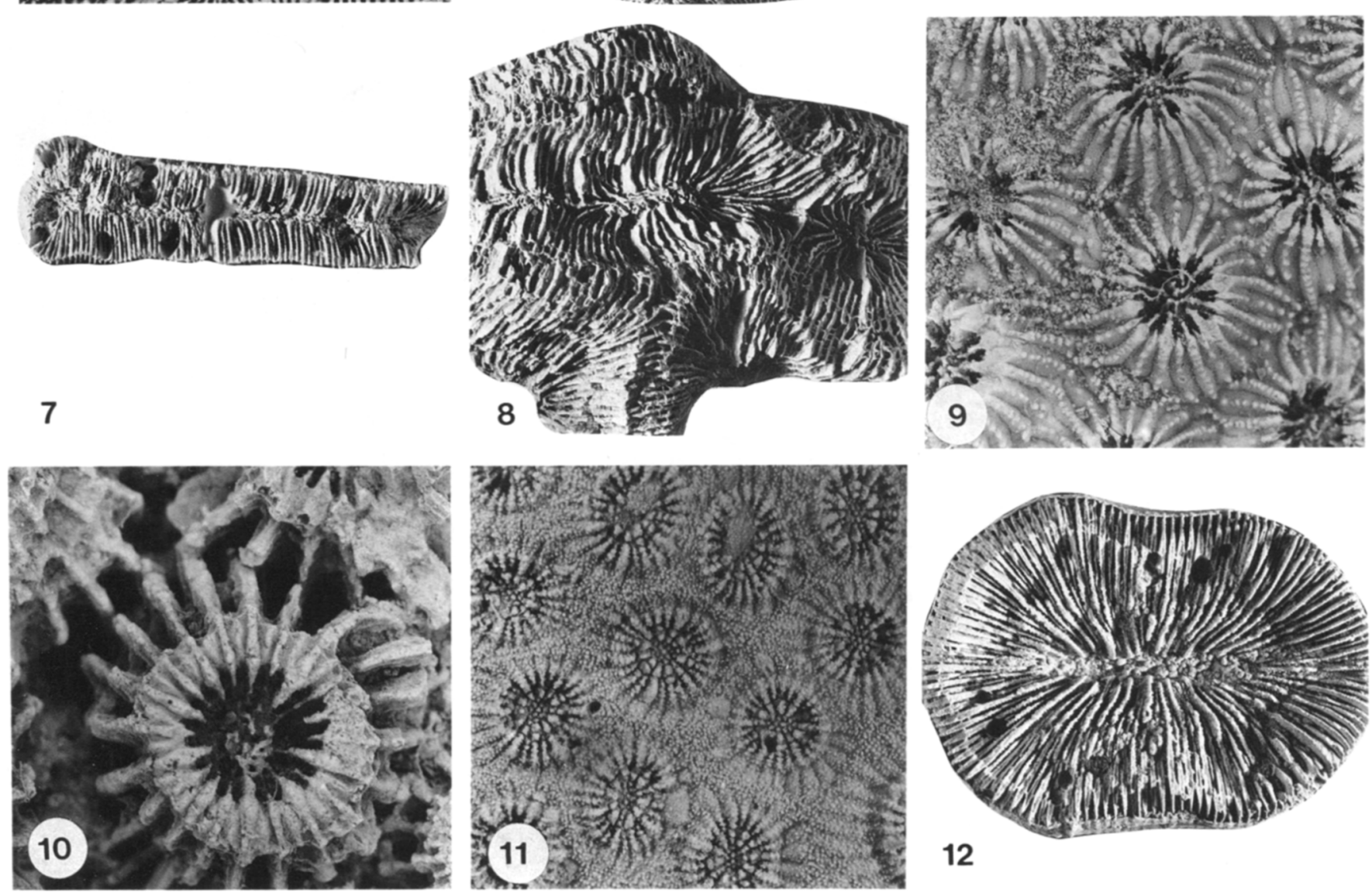

12 

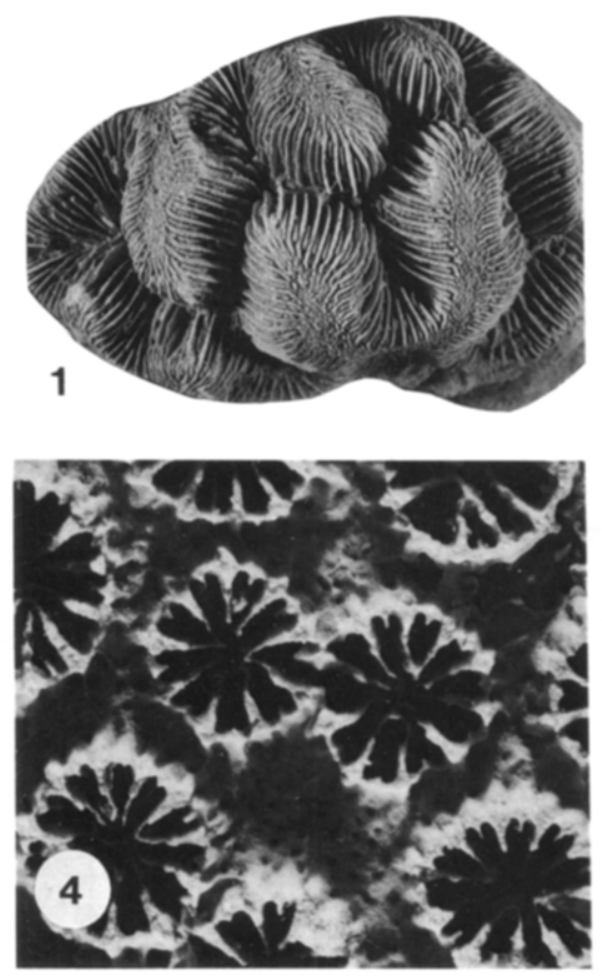

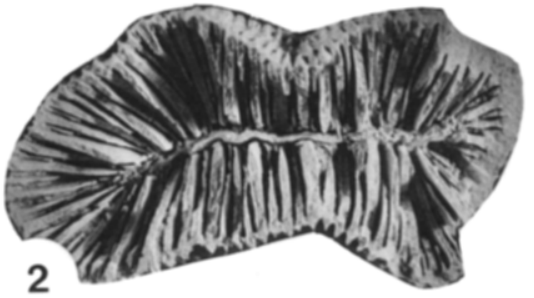

5

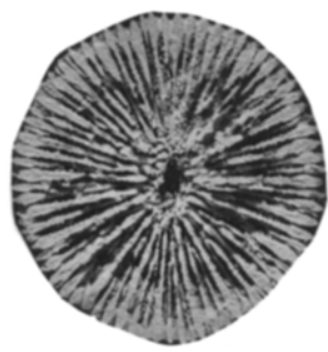

6
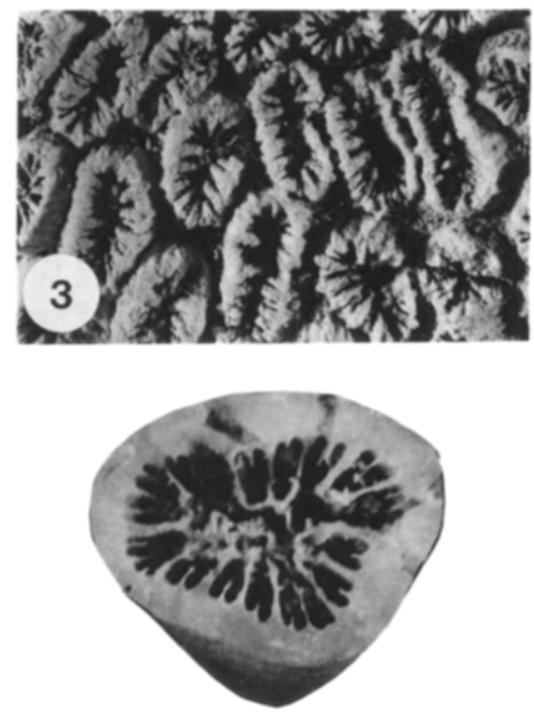

FIGURE 3-Common genera of reef corals collected in the Neogene sequence of the northern Dominican Republic. Calical surfaces. 1, Meandrina (Meandrina) braziliensis, NMB D6013, upper Miocene, NMB loc. 16821, $\times 1$. 2, Meandrina (Placocyathus) costatus, NMB D6012, lower Pliocene, NMB loc. $15822, \times 1.3$, Dichocoenia tuberosa, NMB D6014, lower Pliocene, NMB loc. 15826, $\times 2.4$, Galaxea excelsa, NMB D6010, upper Miocene, NMB loc. 15855, × 5. 5, Antillia dentata, NMB D6011, upper Miocene, NMB loc. 15807, × 1. 6, Eusmilia sp. A, NMB D6024, upper Miocene, NMB loc. $15806, \times 5$.

extinction $=6.80$, d.f. $=6, P>0.25$; at 4-2 Ma, chi-square for origination $=6.54$, d.f. $=6, P>0.25$, chi-square for extinction $=4.62$, d.f. $=6, P>0.25)$. Unusually high rates $(>20$ percent per 2 m.y.) occurred between 4 and $2 \mathrm{Ma}$, especially in the pocilloporids, agariciids, and meandrinids. Moderately high rates (10-20 percent per 2 m.y.) were present in the faviids and poritids during this time. High rates in the siderastreids appear delayed until 2-0 Ma. In contrast, rates of extinction in the mussids remained low throughout the Miocene to Recent.

Genus-level patterns. - The composite range chart for genera (Figure 5) reveals some of the same general patterns described above for species, with periods of Caribbean extinction mainly in the late Oligocene through early Miocene (seven genera, three of which live today in the Indo-Pacific) and in the latest Miocene through early Pleistocene (15 genera and subgenera, nine of which live today in the Indo-Pacific and one in Brazil). Neogene originations were concentrated during the late Miocene in the agariciids (three genera) and mussids (three genera), and in the free-living corals (three genera and subgenera). In contrast to species-level patterns, however, Dendrogyra and Mussismilia are the only genera that appeared in the Caribbean after the Miocene, and both genera occurred earlier in the Mediterranean. Thus, much of the post-Miocene evolutionary history of the reef corals in the Caribbean region has involved a sharp decline in total number of genera with little or no change in overall species richness (see Budd et al., 1994). Many of the genera that became extinct in the Caribbean still live today in the Indo-Pacific. Some extinct Caribbean genera that survived in the Indo-Pacific (i.e., Pocillopora, Gardineroseris, Pavona, and Psammocora) are important components of modern eastern Pacific reefs.

\section{SUMMARY AND CONCLUSIONS}

Preliminary examination of the stratigraphic distributions of Neogene to Recent Caribbean reef corals suggests the following.

1. Turnover in the fauna was especially pronounced during the Plio-Pleistocene (4-1 Ma) with high extinction rates in all families except the Mussidae. The higher taxa that became ex-

FIGURE 2-Common genera of reef corals collected in the Neogene sequence of the northern Dominican Republic. Calical surfaces. 1, Porites macdonaldi, NMB D5846, upper Miocene, NMB loc. 16883, $\times 10.2$, Goniopora hilli, NMB D5853, upper Miocene, NMB loc. $15861, \times 5.3$, Favia sp. A, NMB D6017, upper Miocene, NMB loc. 16855, ×2. 4, Diploria sp. B, NMB D6018, lower Pliocene, NMB loc. $16817, \times 2.5$, Manicina (Manicina) puntagordensis, NMB D6019, lower Pliocene, NMB loc. 16859, $\times 1$. 6, Manicina (Teleiophyllia) sp. B, NMB D6020, lower Pliocene, NMB loc. 16862, $\times 1.7$, Thysanus excentricus, NMB D6021, upper Miocene, NMB loc. 16910, $\times 1.8$, Colpophyllia natans, NMB D6022, lower Pliocene, NMB loc. 16818, $\times 1.9$, Montastraea limbata, USNM 66827 (NF439), Neogene, USGS loc. 7775, $\times 5$. 10, Montastraea cylindrica, USNM 155277, Neogene, Nivaje Shale, $\times 5$. 11, Solenastrea bournoni, NMB D5603, upper Miocene, NMB loc. 16811 , $\times 5$. 12, Trachyphyllia bilobata, NMB D6023, upper Miocene, NMB loc. $16910, \times 1$. 


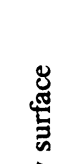<smiles>C=CC(=O)O</smiles>

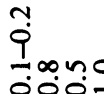
o. $0 .-$ 낱뮬 융융흉

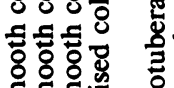

오론

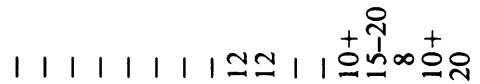
| 111118

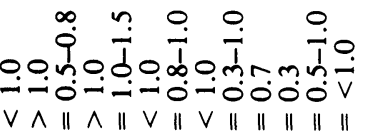

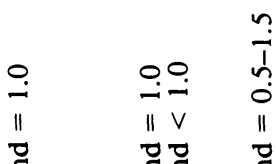

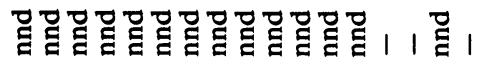

Tio0

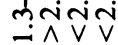
|| $\|$ || $\|$ $8 \nabla 8 \nabla$

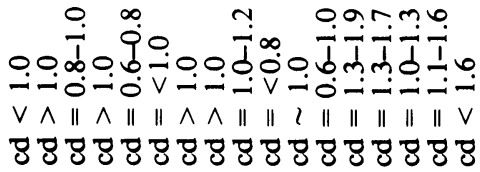

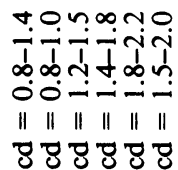

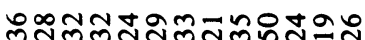

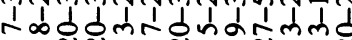

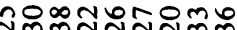

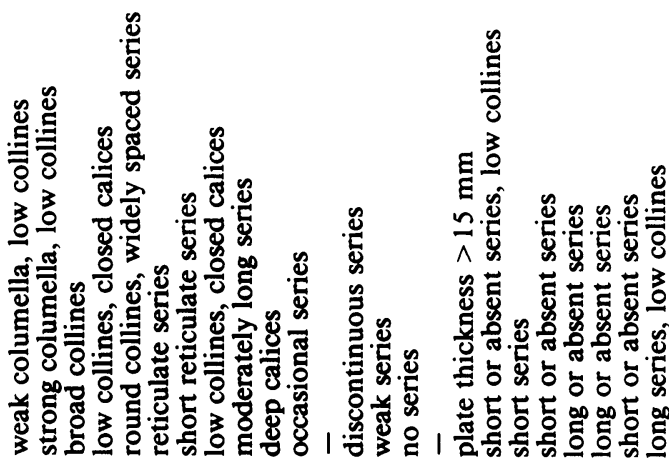

$\Sigma \Sigma \Sigma \Sigma$

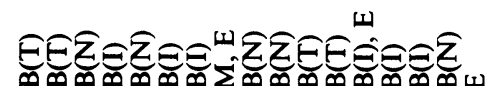

w

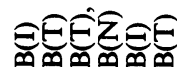

nanoa-0amataopobonmrNnoo

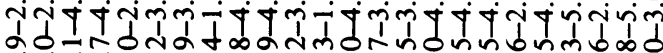

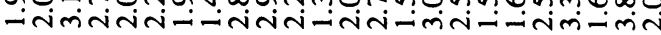
|| || || || || || || || || || || || || || || || || || || || || || || ||

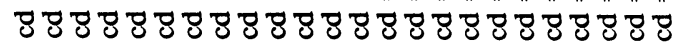

w

$\sum \omega$

Sरะ
กิ

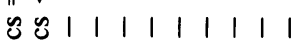

递

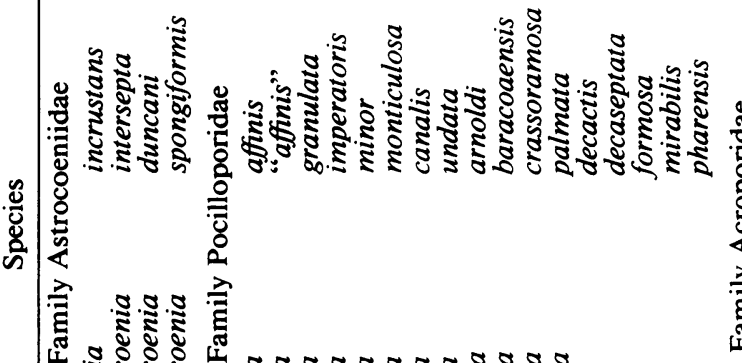

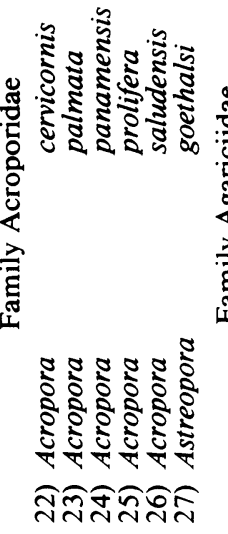

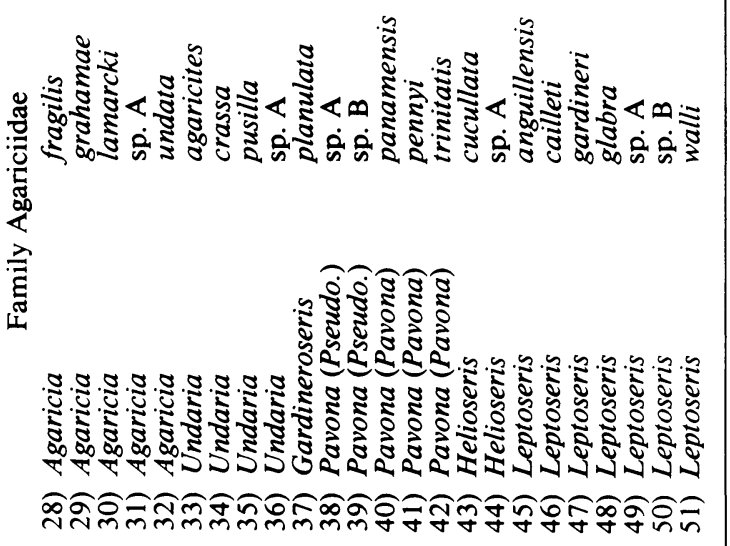




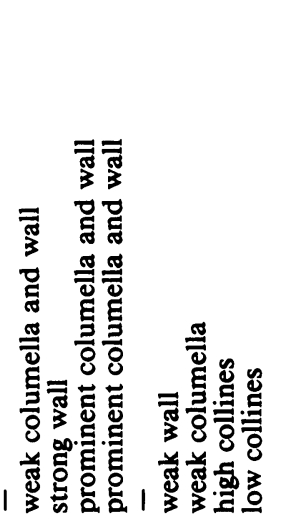<smiles>C[C@@H]1CC1[C@@H]1C[C@H]1C</smiles>

零

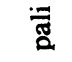

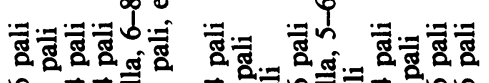

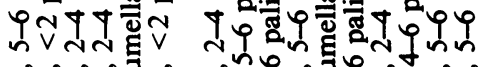

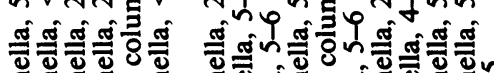

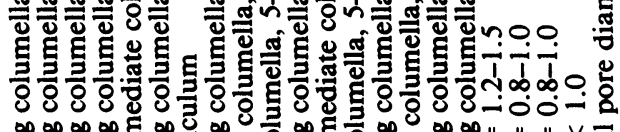

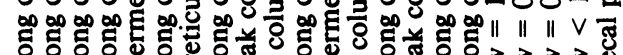

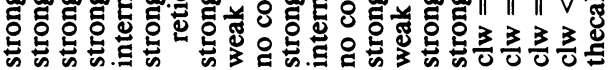

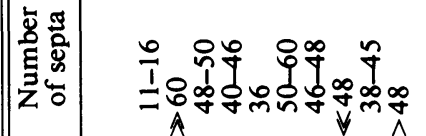<smiles>COCCO</smiles>

oononnoonn

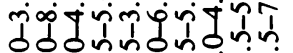

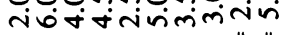
|| || || || || || || 2 || ||

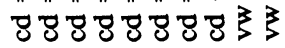

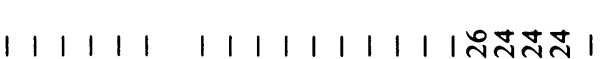
il il

유웅

हू हूँ

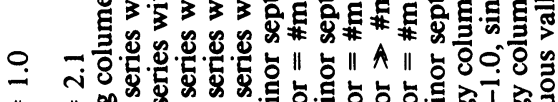

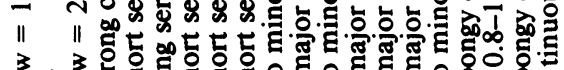

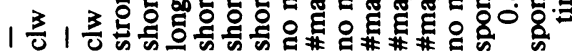

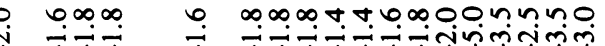

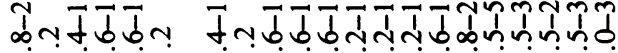
| $\vee\|\mid\|\|v\| v\|\|\|\|\|\|\|\|\|\|\|\|\|\|$

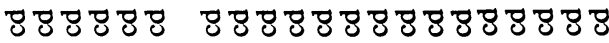

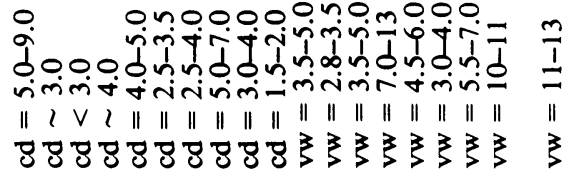

$\Sigma \Sigma \Sigma \Sigma \sum \Sigma \Sigma \Sigma \Sigma \Sigma \Sigma$

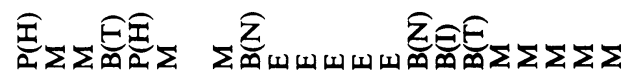

ิㅗํํํำ
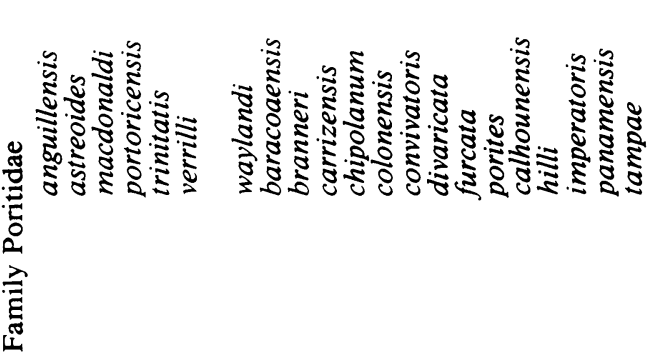
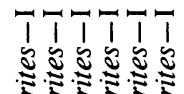

5isos

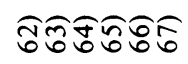

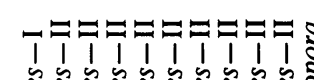

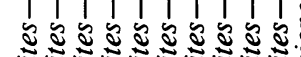

o. o o o jo

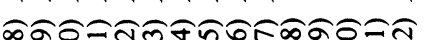
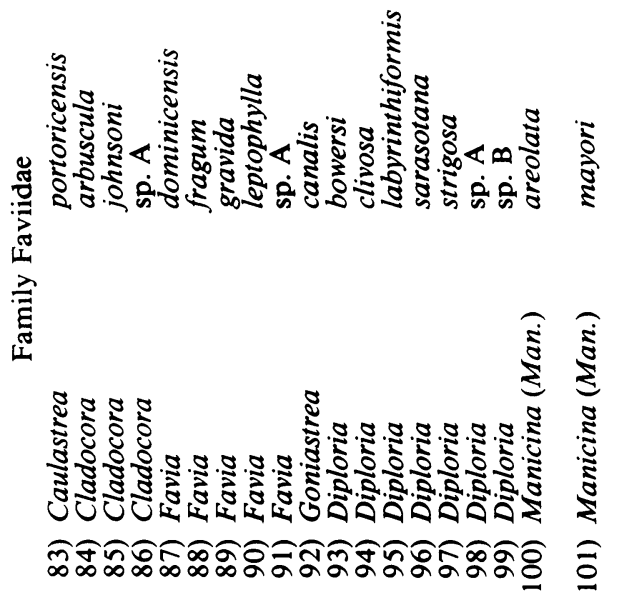


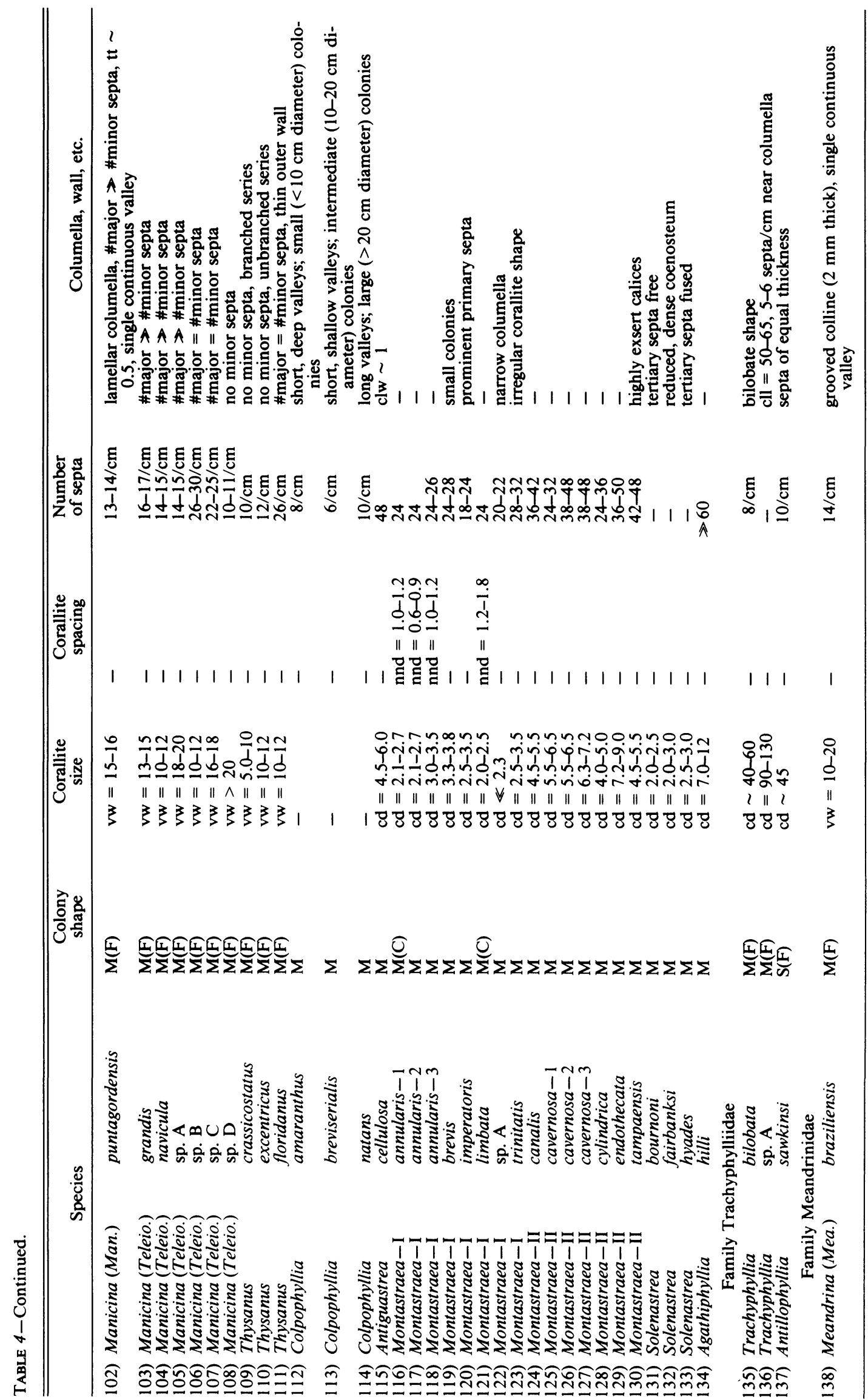




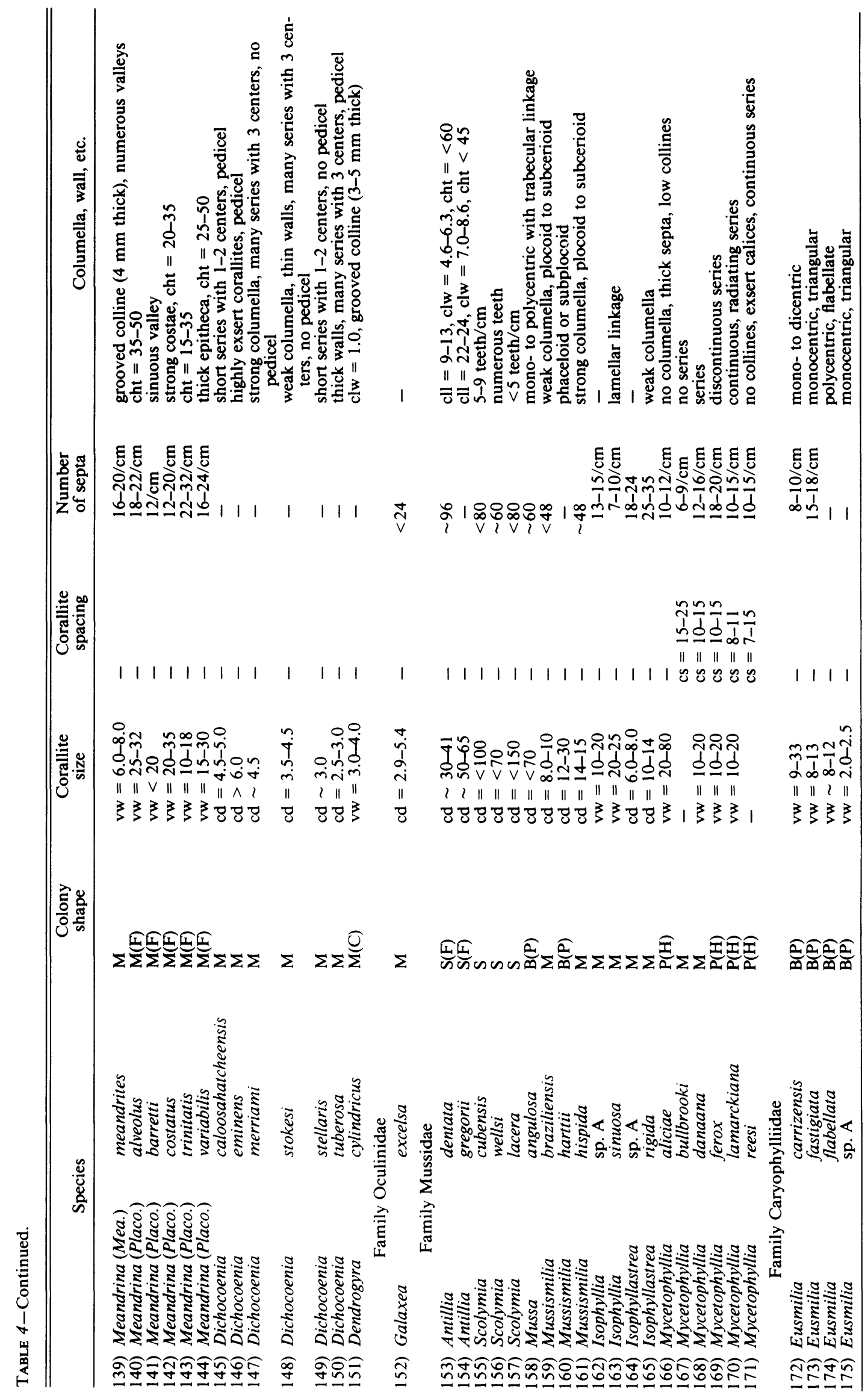




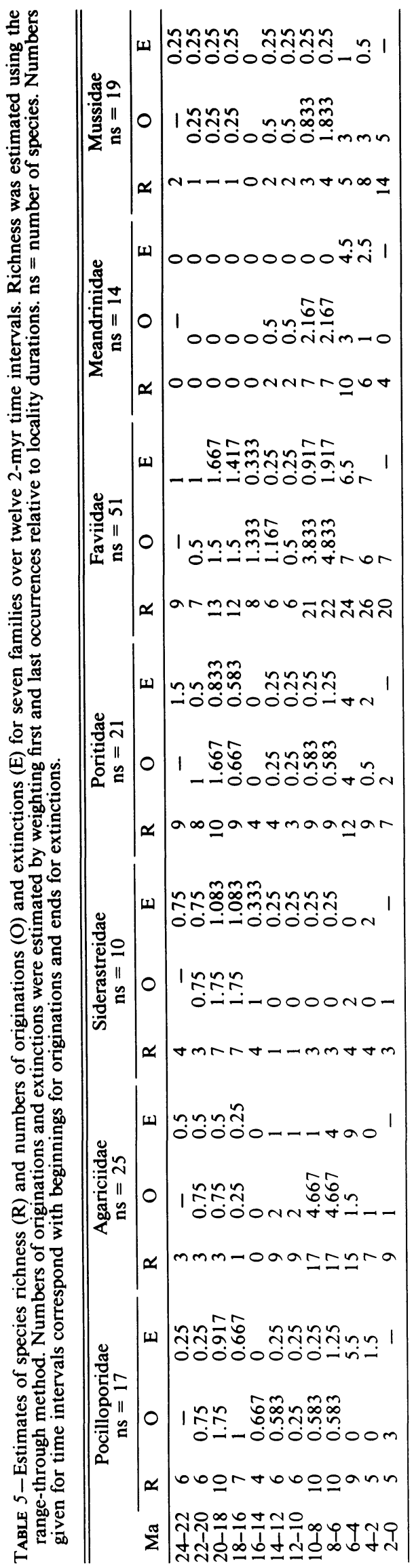

tinct in the Caribbean include Stylophora, Pocillopora, Gardineroseris, Pavona, Goniopora, Caulastrea, Trachyphyllia, Teleiophyllia, Thysanus, Placocyathus, Antillia, and Mussismilia. Of these 12 taxa, the first seven occur today in the Indo-Pacific, and three of the seven (Pocillopora, Gardineroseris, and Pavona) are common in the impoverished fauna of the modern eastern Pacific, which consists of seven genera total, only two of which occur in the modern Caribbean. One extinct genus (Mussismilia) lives today in Brazil. The remaining four taxa became globally extinct and consist entirely of free-living corals. Thus, the $\mathrm{Ca}$ ribbean reef coral fauna did not achieve a distinctively modern aspect ( $>60$ percent generic similarity) until the early to middle Pleistocene.

2. The fact that extinct Caribbean genera are among the most important constituents of the modern eastern Pacific fauna suggests that the dispersal hypothesis for the origin of the eastern Pacific fauna may be over-simplified and needs to be re-evaluated in light of fossil occurrences (see discussion in Budd, 1989). Both the eastern Pacific and Brazilian faunas may partially represent relicts of the more generically diverse Neogene Caribbean reef-coral fauna.

3. In contrast to the apparent synchrony of Plio-Pleistocene extinctions, extinctions of taxa that were common during the late Oligocene were scattered throughout the early to middle Miocene. Included among these taxa were the then mono- or paucispecific Caribbean genera such as Astrocoenia, Astreopora, Pironastrea, Goniastrea, Antiguastrea, and Agathiphyllia. Of these, only Astreopora and Goniastrea live today in the IndoPacific. The others are globally extinct.

4. The fact that extinction patterns differed little among families during Plio-Pleistocene time indicates that the accelerated extinction was not taxonomically selective and therefore may have been part of a larger scale biotic crisis, ultimately caused by external abiotic factors. High extinction rates have also been reported at this time in Caribbean molluscs (Stanley and Campbell, 1981; Stanley, 1986) and bryozoans (A. H. Cheetham, personal commun.), but not in Indo-Pacific corals (Potts, 1984; Veron and Kelley, 1988). The temporal correspondence of accelerated evolutionary rates in several unrelated Caribbean groups suggests that the abiotic factors may have been regional in extent. Although the roles of specific factors are still debated, all appear directly or indirectly related to long-term, unidirectional changes in climate and/or ocean circulation in association with closure of the Isthmus of Panama at approximately 3.5 Ma (Coates et al., 1992).

5. Originations during Plio-Pleistocene turnover were highest in the families Acroporidae, Poritidae, Faviidae, and Mussidae, but occurred only at the species level. Many dominant shallowwater components of modern Caribbean reefs arose during this period of time, including the common modern species Acropora palmata, Diploria strigosa, and Porites astreoides and the Montastraea annularis complex.

6. Relatively high origination rates also prevailed during the late Miocene, when large numbers of species arose in the agariciids and in the free-living faviids and meandrinids. With the exception of Psammocora and Galaxea (both common today in the Indo-Pacific, with Psammocora extending to the eastern

FIGURE 4-Composite stratigraphic range charts for all Neogene Caribbean reef coral species. Taxa are arranged by families. Numbers for each species correspond with those in Appendix. Asterisks indicate Recent Caribbean occurrences; parentheses indicate Recent occurrences in Brazil; pluses indicate pre-Miocene occurrences; dashes delineate genera or subgenera within families. 

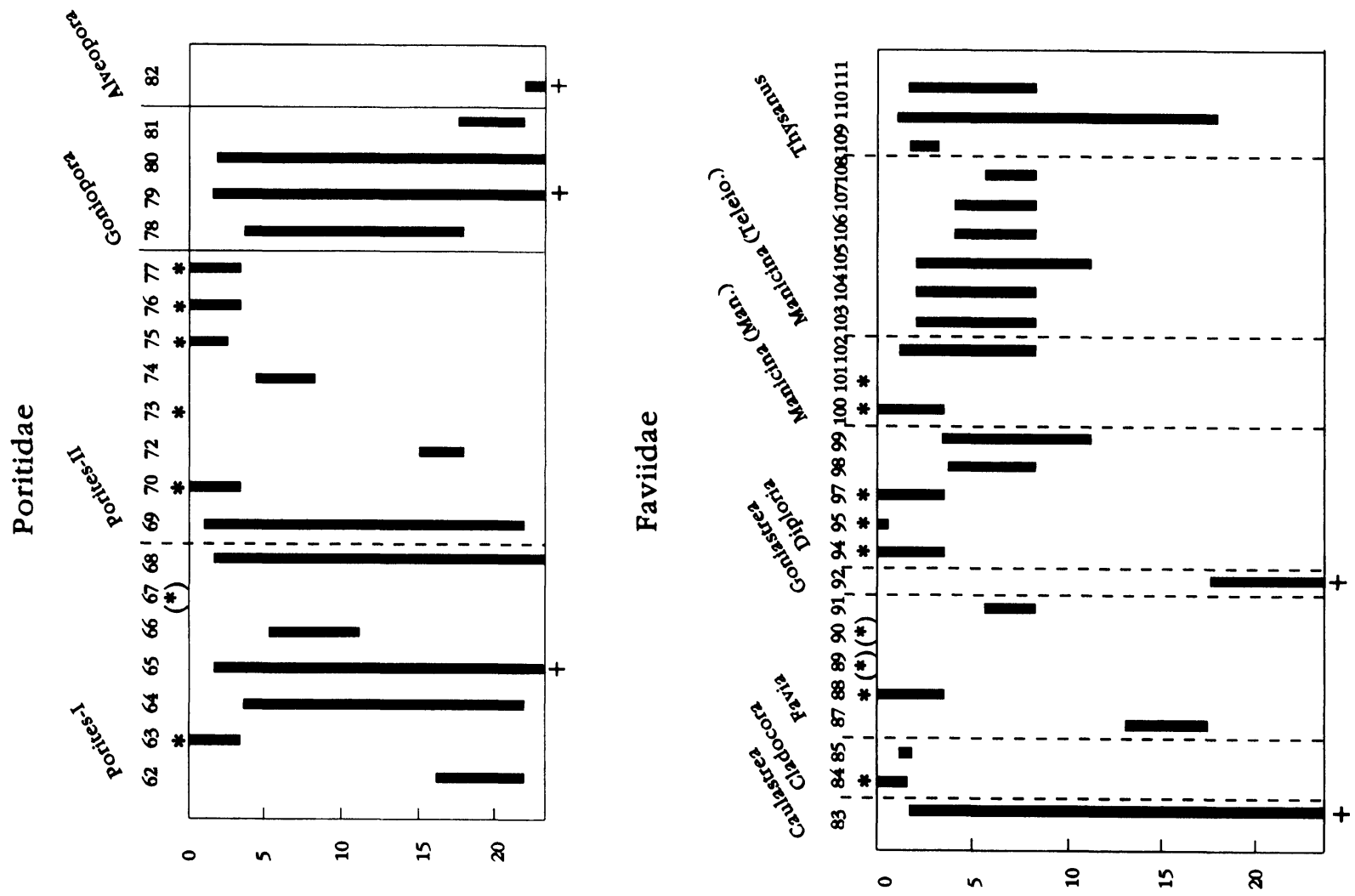

eW
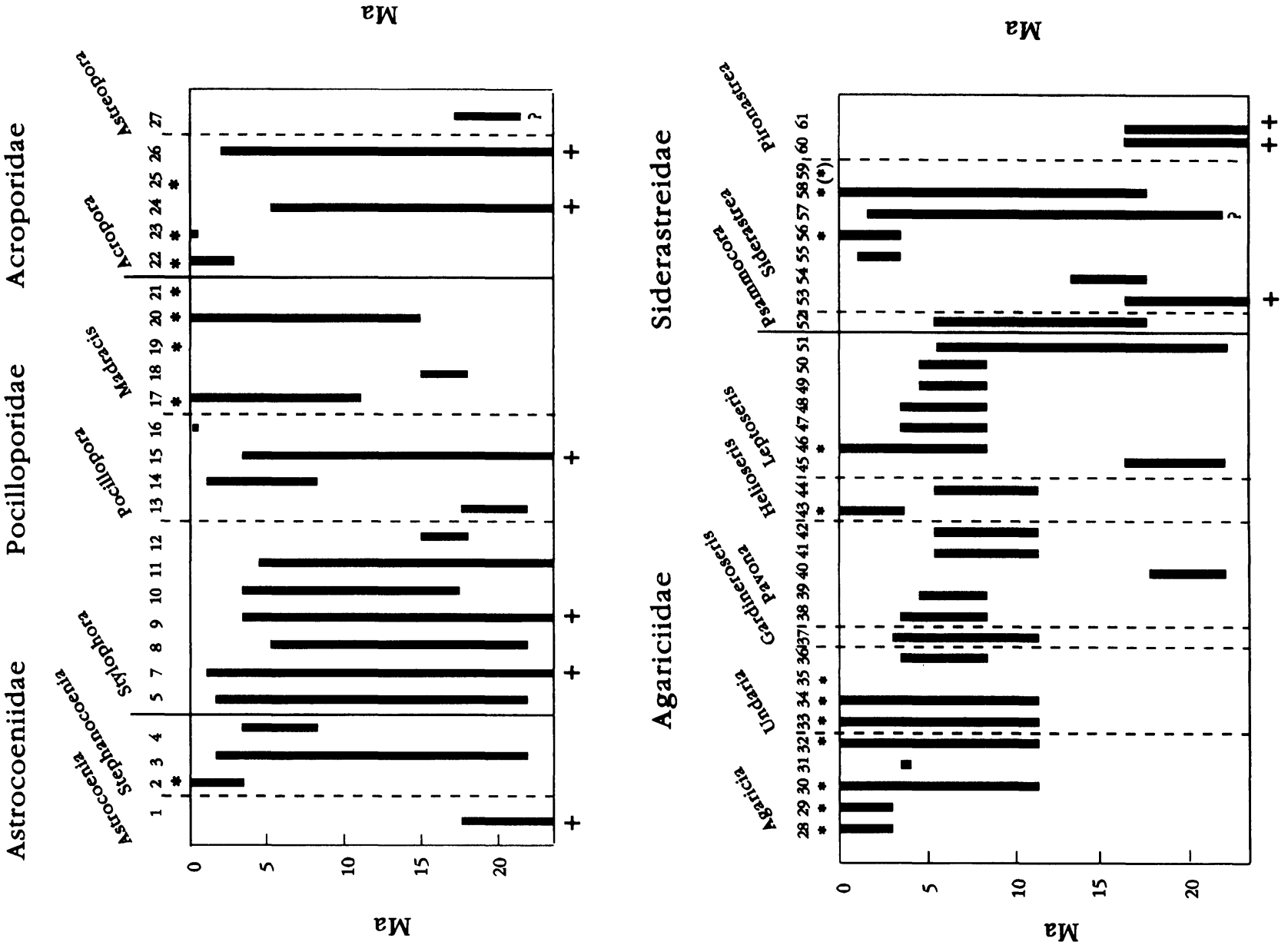

EW 
ปั.

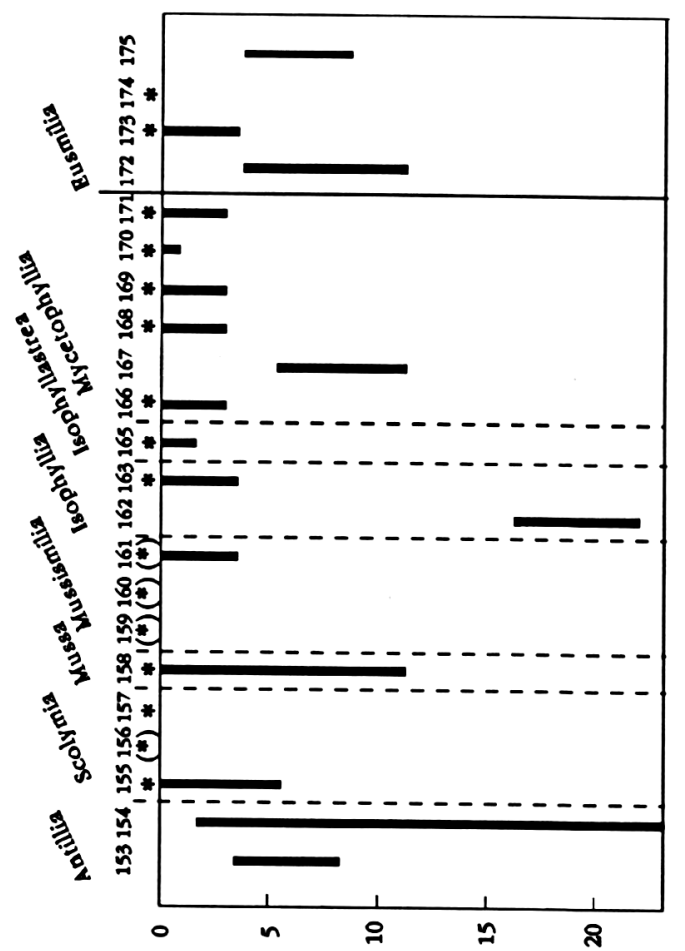

EW
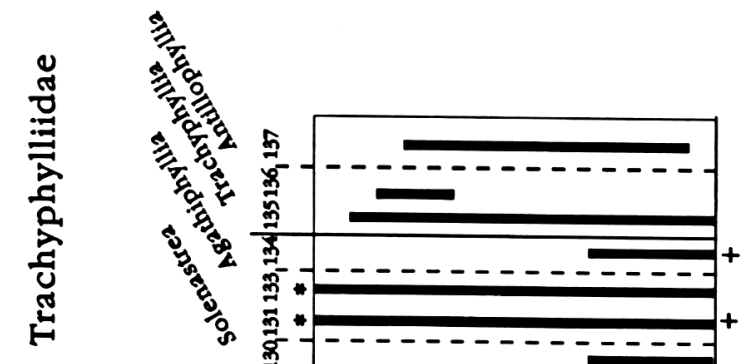

-

兽-1-.-.-.-.-.-

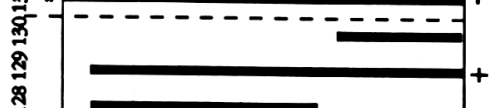

ชูป

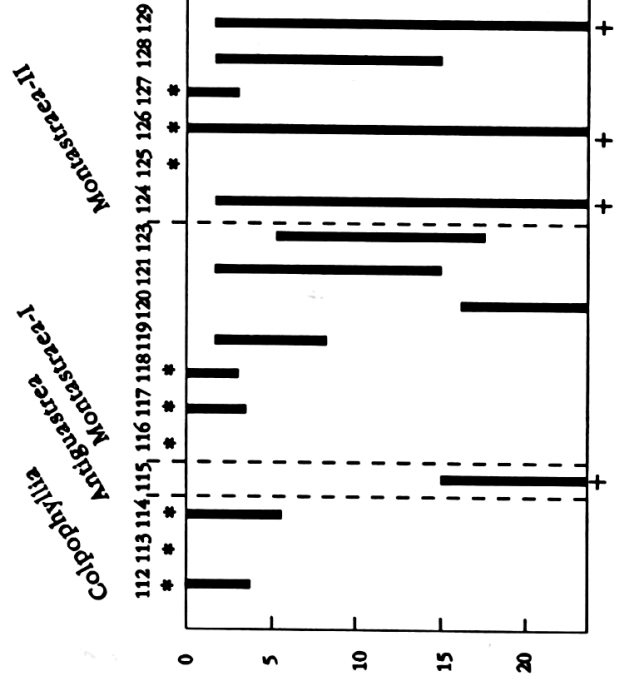

EW

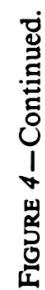
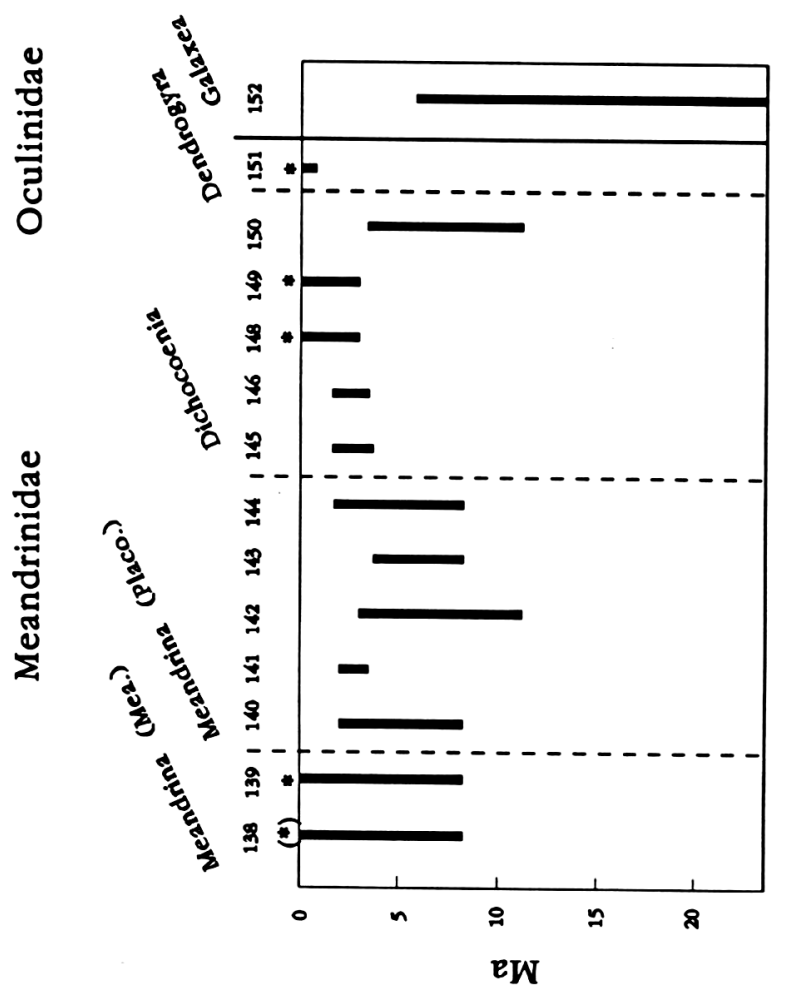


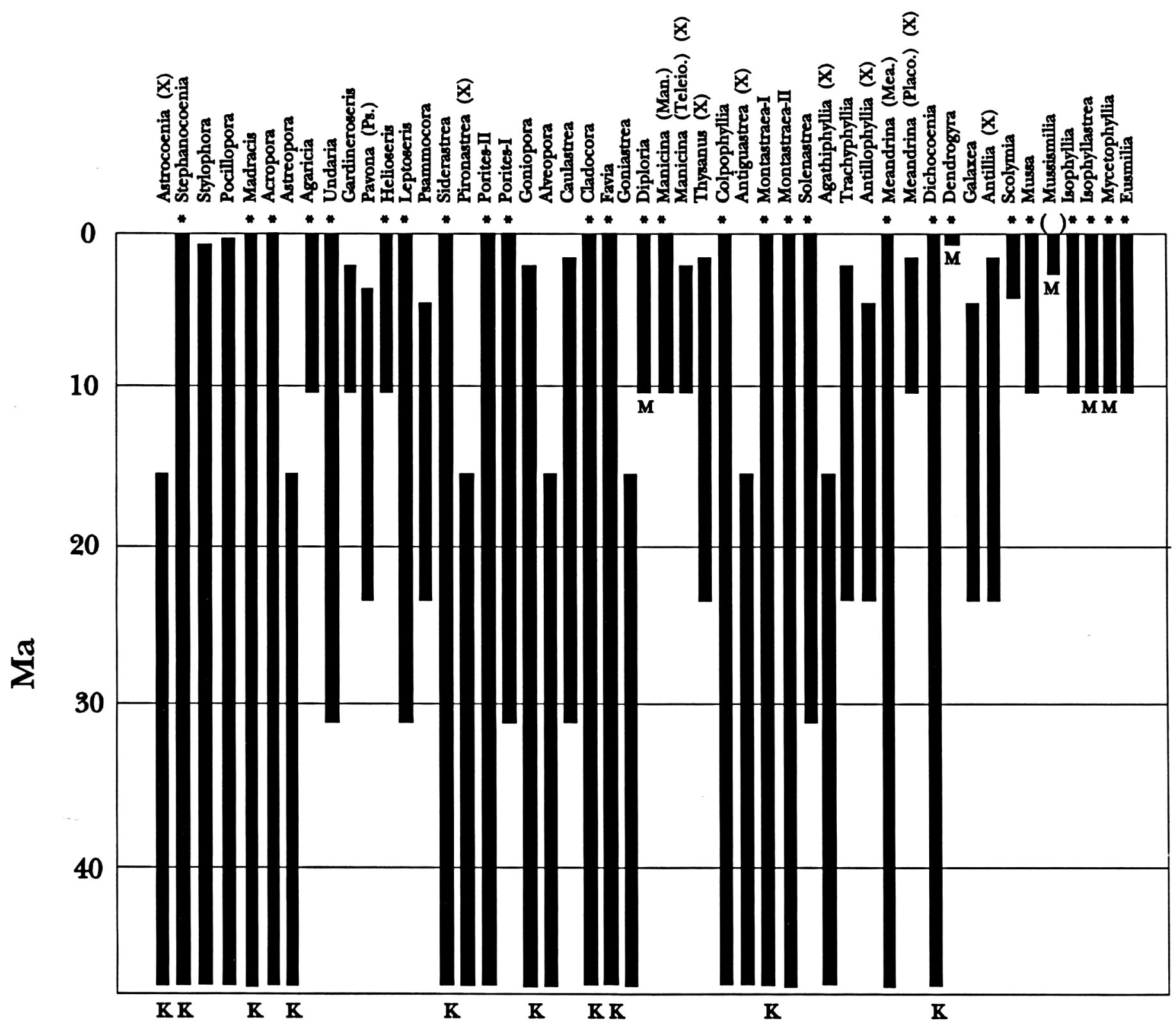

FIGURE 5-Composite stratigraphic range chart for Caribbean reef coral genera. Only genera with Neogene occurrences are shown. Asterisks indicate Recent Caribbean occurrences; parentheses indicate Recent occurrences in Brazil; "K"s indicate possible Cretaceous occurrences; " $M$ "s indicate possible post-middle Miocene Mediterranean emigrants (after Wells, 1956). Genera marked "(X)" are now extinct.

Pacific), as well as Antillophyllia, relatively few Caribbean extinctions took place during this time interval.

7. Because of the high numbers of generic extinctions during Plio-Pleistocene and early to middle Miocene time, and because of the lack of new genera in the Caribbean since the late Miocene, generic richness in the Caribbean dropped sharply from Neogene to Recent time. Of the 41 genera occurring in the late Miocene and Pliocene of the Caribbean, only 68 percent live there today. In part, this drop in richness may be related to increasing isolation of the Caribbean region and complete breakdown in dispersal from the Mediterranean during the late Miocene, and from the Indo-Pacific during the Pliocene. Despite the drop in generic richness, species richness remained relatively constant over the same time interval. Thus, different patterns prevail at the species and genus levels, and genus-level patterns cannot be used to approximate species-level patterns.

\section{ACKNOWLEDGMENTS}

We thank S. D. Cairns and D. C. Potts for reviewing the manuscript; J. Geister, P. Jung, and J. B. Saunders for providing collections in the Dominican Republic; and J. B. C. Jackson, A. G. Coates, and J. A. Obando for help with field work and collections in Costa Rica. L. S. Collins, T. M. Cronin, and J. Geister provided additional collection and locality information; and R. Panchaud and J. Golden assisted in specimen curation. S. Dahint prepared many of the photographs. Funds were provided by NSF grant EAR-9219138 to AFB, NSF grant INT9102569 to TAS, and an NSF/NATO postdoctoral fellowship to $\mathrm{KGJ}$. 

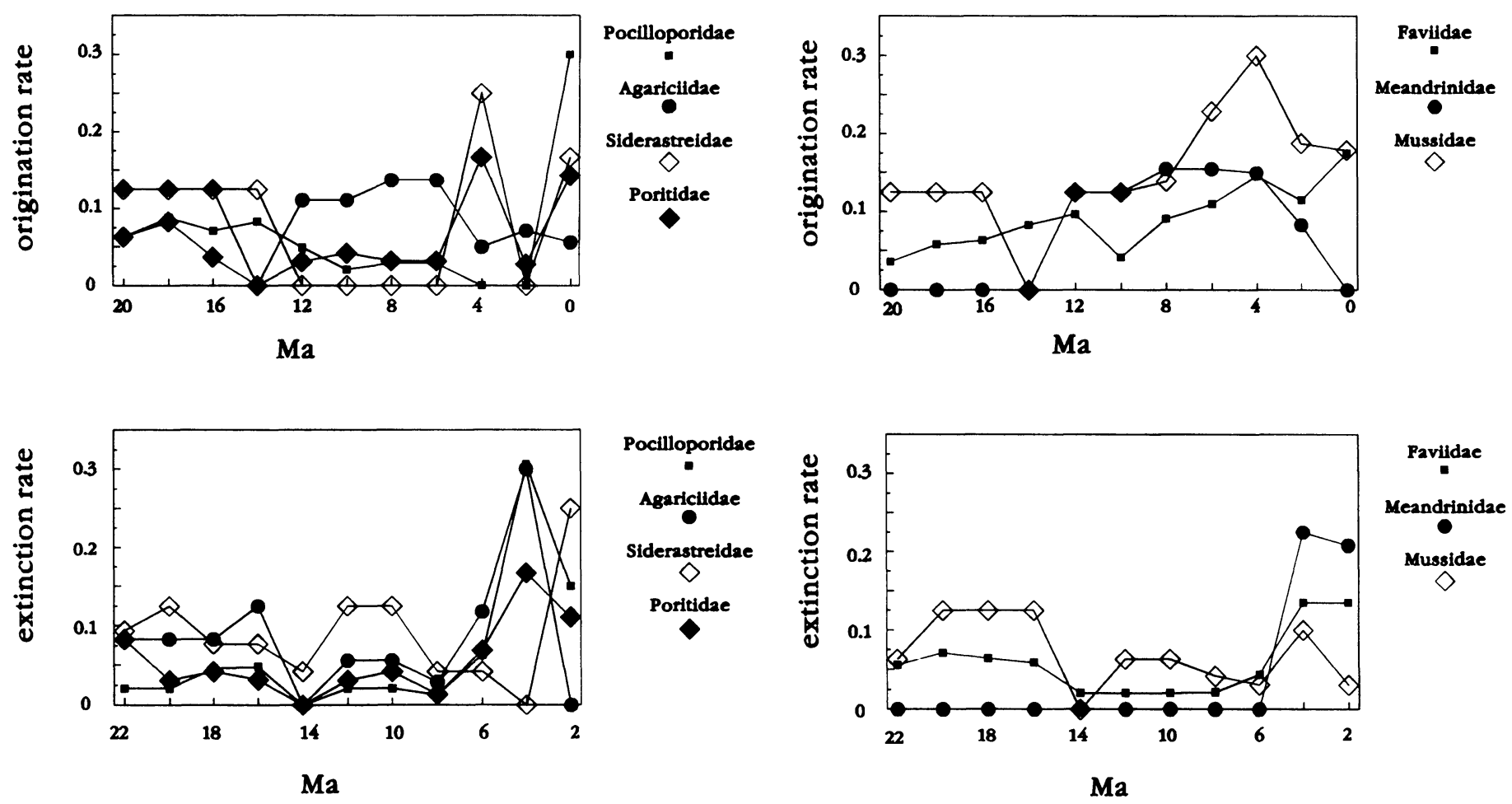

FIGURE 6-Extinction and origination rates per 2-m.y. time intervals for species within seven families. Rates were calculated by dividing the number of originations and extinctions in each interval in Table 5 by species richness. Numbers on the horizontal axis correspond with beginnings of time intervals for origination rates, and with ends of time intervals for extinction rates.

\section{REFERENCES}

AUBRY, M.-P. 1993. Calcareous nannofossil stratigraphy of the Neogene formations of eastern Jamaica. In R. M. Wright and E. R. Robinson (eds.), Biostratigraphy of Jamaica. Geological Society of America, Memoir 182:131-178.

Barry, J. C., L. J. Flynn, and D. R. Pilbeam. 1990. Faunal diversity and turnover in a Miocene terrestrial sequence, p. 381-421. In R. M. Ross and W. D. Allmon (eds.), Causes of Evolution: A Paleontological Perspective. University of Chicago Press, Chicago.

Berggren, W. A., D. V. Kent, and J. A. van Couvering. 1985. Neogene geochronology and chronostratigraphy, p. 211-260. In N. J. Snelling (ed.), The Chronology of the Geological Record. Geological Society of London, Memoir 10.

BLACUT, G., AND R. M. KLEINPELL. 1969. A stratigraphic sequence of benthonic smaller foraminifera from the La Boca Formation, Panama Canal Zone. Cushman Foundation for Foraminiferal Research, Contributions, 20:1-22.

BOLD, W. A. VAN DEN. 1970. Ostracoda of the lower and middle Miocene of St. Croix, St. Martin, and Anguilla. Caribbean Journal of Science, 10:35-61.

- 1971. Ostracoda of the Coastal Group of Formations of Jamaica. Gulf Coast Association of Geological Societies, Transactions, 1:325348.

- 1975. Ostracodes from the Late Neogene of Cuba. Bulletins of American Paleontology, 68:121-167.

Bollı, H. M. 1970. The foraminifera of sites 23-31, leg 4. Initial Reports of the Deep Sea Drilling Project, 4:577-643.

BuDd, A. F. 1989. Biogeography of Neogene Caribbean reef corals and its implications for the ancestry of eastern Pacific reef corals. Association of Australasian Palaeontologists, Memoirs, 8:219-230.

- 1991. Neogene paleontology in the northern Dominican Republic. 11. The family Faviidae (Anthozoa: Scleractinia). Part I. Bulletins of American Paleontology, 101:5-83.

- 1993. Variation within and among morphospecies of Montastraea. Courier Forschungs-Institut Senckenberg, 164:241-254.

—, AND A. G. COATES. 1992. Non-progressive evolution in a clade of Cretaceous Montastraea-like corals. Paleobiology, 18:425-446.
-, J. C. Edwards, AND K. G. Johnson. 1989. Miocene coral assemblages in Anguilla, BWI, and their implications for the interpretation of vertical succession on fossil reefs. Palaios, 4:264-275.

-, Johnson, K. G., AND T. A. Stemann. 1994. Plio-Pleistocene extinctions and the origin of the modern Caribbean reef-coral fauna, p. 7-13. In R. N. Ginsburg (compiler), Proceedings of the Colloquium on Global Aspects of Coral Reefs: health, hazards, history. University of Miami, Miami, Florida.

- T. A. Stemann, ANd R. H. Stewart. 1992. Eocene Caribbean reef corals: a unique fauna from the Gatuncillo Formation of Panama. Journal of Paleontology, 66:578-602.

Bryant, J. D., B. J. MacFadden, AND P. A. Mueller. 1992. Improved chronologic resolution of the Hawthorn and Alum Bluff Groups in northern Florida: implications for Miocene chronostratigraphy. Geological Society of America Bulletin, 104:208-218.

Carter, J. G., and T. J. Rossbach. 1989. Correlation chart, Gulf and Atlantic Coasts of North America. Biostratigraphy Newsletter, 3, $48 \mathrm{p}$.

Coates, A. G., Et Al. 1992. Closure of the isthmus of Panama: the near-shore marine record of Costa Rica and western Panama. Geological Society of America Bulletin, 104:814-828.

FosTER, A. B. 1986. Neogene paleontology in the northern Dominican Republic. 3. The family Poritidae (Anthozoa: Scleractinia). Bulletins of American Paleontology, 90:47-123.

1987. Neogene paleontology in the northern Dominican Republic. 4. The genus Stephanocoenia (Anthozoa: Scleractinia: Astrocoeniidae). Bulletins of American Paleontology, 93:5-22.

Frost, S. H. 1977. Miocene to Holocene evolution of Caribbean province reef-building corals. Third International Coral Reef Symposium, Proceedings, 2:353-360.

- AND R. L. Langenheim. 1974. Cenozoic Reef Biofacies. Northern Illinois University Press, DeKalb, Illinois, 388 p.

- AND M. P. WEISs. 1979. Patch-reef communities and succession in the Oligocene of Antigua, West Indies. Geological Society of America Bulletin, Part II, 90:1094-1141.

—, J. L. Harbour, D. K. Beach, M. J. Realini, and P. M. Harris. 
1983. Oligocene reef tract development, southwestern Puerto Rico. Sedimenta IX, University of Miami, Coral Gables, Florida, 141 p.

GEISTER, J. 1975. Riffbau und geologische Entwicklungsgeschichte der Insel San Andrés (westliches Karibisches Meer, Kolumbien). Stuttgarter Beiträge zur Naturkunde, B, 15, 203 p.

- 1982. Pleistocene reef terraces and coral environments at Santo Domingo and near Boca Chica, southern coast of the Dominican Republic. Ninth Caribbean Geological Conference (Santo Domingo, 1980), Transactions, 2:689-703.

- 1992. Modern reef development and Cenozoic evolution of an oceanic island/reef complex: Isla de Providencia (western Caribbean Sea, Colombia). Facies, 27:1-70.

GlynN, P. W., AND G. M. Wellington. 1983. Corals and Coral Reefs of the Galápagos Islands. University of California Press, Berkeley, $330 \mathrm{p}$.

GonzÁlez, L. A., H. M. Ruiz, A. F. Budd, ANd V. MonNell. 1992. A late Miocene barrier reef in Isla de Mona, Puerto Rico. Geological Society of America, Abstracts with Programs, 24(7):A350.

Jones, D. S., B. J. MacFadden, S. D. Webb, P. A. Mueller, D. A. HoDDELL, AND T. M. CRONIN. 1991. Integrated geochronology of a classic Pliocene fossil site in Florida: linking marine and terrestrial biochronologies. Journal of Geology, 99:637-648.

KeRR, D. R., AND S. M. KIDWELl. 1991. Late Cenozoic sedimentation and tectonics, western Salton Trough, California, p. 397-416. In M. J. Walawender and B. B. Hanan (eds.), Geological Excursions in Southern California and Mexico. Geological Society of America, Guidebook, 1991 Annual Meeting, Boulder, Colorado.

Knowlton, N., E. Weil, L. A. Weigt, AND H. M. Guzman. 1992. Sibling species in Montastraea annularis, coral bleaching, and the coral climate record. Science, 255:330-333.

KOCH, C. F., AND J. P. MORGAN. 1988. On the expected distribution of species ranges. Paleobiology, 14:126-138.

LABOREL, J. 1969. Madréporaires et hydrocoralliaires récifaux des cotes brésiliennes. Institut Océanographique, Annales, 47:171-229.

LidDELL, W. D., AND S. L., OHLHORST. 1988. Comparison of western Atlantic coral reef communities. Sixth International Coral Reef Symposium, Proceedings, 3:281-286.

MARShall, C. R. 1990. Confidence intervals on stratigraphic ranges. Paleobiology, 16:1-10.

MAURRASSE, F. 1990. Stratigraphic correlation for the circum-Caribbean region, Pl. 4, 5. In G. Dengo and J. E. Case (eds.), The Caribbean Region. The Geology of North America, Volume H. Geological Society of America, Boulder, Colorado.

MEEDER, J. F. 1987. The paleontology, petrology, and depositional model of the Pliocene Tamiami Formation, southwest Florida (with special reference to corals and reef development). Unpubl. Ph.D. dissertation, University of Miami, Coral Gables, Florida, 748 p.

Potrs, D. C. 1984. Generation times and the Quaternary evolution of reef-building corals. Paleobiology, 10:48-58.

, A. F. BUDD, AND R. L. GARThWATte. 1993. Soft tissue vs. skeletal approaches to species recognition and phylogeny reconstruction in corals. Courier Forschung-Institut Senckenberg, 164:221-231.

Saunders, J. B., P. Jung, ANd B. Buu-Duval. 1986. Neogene Paleontology in the northern Dominican Republic. 1. Field surveys, lithology, environment, and age. Bulletins of American Paleontology, $89,79 \mathrm{p}$.

StANLEy, S. M. 1986. Anatomy of a regional mass extinction: PlioPleistocene decimation of the western Atlantic bivalve fauna. Palaios, 1:17-36.

StANLey, S. M., AND L. D. CAMPBell. 1981. Neogene mass extinction of western Atlantic molluscs. Nature, 293:457-459.

StemanN, T. A. 1991. Evolution of the reef-coral family Agariciidae (Anthozoa: Scleractinia) in the Neogene through Recent of the Caribbean. Unpubl. Ph.D. dissertation, University of Iowa, Iowa City, $321 \mathrm{p}$.

VAUGHAN, T. W. 1917. The reef-coral fauna of Carrizo Creek, Imperial County, California and its significance. U.S. Geological Survey Professional Paper, 98T:355-386.

- 1919. Fossil corals from Central America, Cuba, and Porto Rico with an account of American Tertiary, Pleistocene, and Recent coral reefs. U.S. National Museum Bulletin, 103:189-524.

the Dominican Republic. Bulletin of the Museum of Comparative Zoology, Harvard College, 67:315-326.
1926. Miocene corals from Trinidad. Papers of the Department of Marine Biology, Carnegie Institution of Washington, 23:107-132.

-, AND J. W. Wells. 1943. Revision of the suborders, families, and genera of the Scleractinia. Geological Society of America, Special Paper 104, $363 \mathrm{p}$.

VERON, J. E. N. 1986. Corals of Australia and the Indo-Pacific. Angula and Robertson Publishers, North Ryde, NSW, Australia, 644 p.

-, AND R. Kelley. 1988. Species stability in reef corals of Papua New Guinea and the Indo Pacific. Association of Australasian Palaeontologists, Memoir 6, $69 \mathrm{p}$.

-, AND M. PICHON. 1979. Scleractinia of Eastern Australia. Part III. Australian Institute of Marine Science, 4, $459 \mathrm{p}$

,-- , AND M. WuSman-Best. 1977. Scleractinia of eastern Australia. Part II. Australian Institute of Marine Science, 3, 233 p.

WeISBORD, N. E. 1971. Corals from the Chipola and Jackson Bluff Formations of Florida. Florida Bureau of Geology, Geological Bulletin, $53,100 \mathrm{p}$.

. 1973. New and little-known corals from the Tampa Formation of Florida. Florida Bureau of Geology, Geological Bulletin, 56, $147 \mathrm{p}$.

1974. Late Cenozoic corals of south Florida. Bulletins of American Paleontology, 66:255-544.

Wells, J. W. 1956. Scleractinia, p. F328-F444. In R. C. Moore (ed.), Treatise on Invertebrate Paleontology, Pt. F, Coelenterata. Geological Society of America and University of Kansas Press, Lawrence.

- AND J. C. LANG. 1973. Systematic list of Jamaican shallow-water Scleractinia. Bulletin of Marine Science, 23:55-58.

ACCEPTED 18 AUguST 1993

\section{APPENDIX}

List of taxa in the compilation including diagnostic morphologic characters used in the recognition of families and genera, and synonyms applied to published faunal lists.

A. Family Astrocoeniidae Koby, 1890: small corallites, simple trabeculae, reduced coenosteum, beaded septal margins.

Astrocoenia Milne Edwards and Haime, 1848: cerioid; two septal cycles; styliform columella; no pali.

1) A. incrustans (Duncan, 1873). Synonyms = Astrocoenia portoricensis Vaughan, 1919.

Stephanocoenia Milne Edwards and Haime, 1848: plocoid or subcerioid; 3 septal cycles; styliform columella; prominent pali.

2) S. intersepta (Lamarck, 1816). Synonyms = Stephanocoenia michelini Milne Edwards and Haime of Geister, 1975, and of Wells and Lang (1973).

3) S. duncani (Foster, 1987). Synonyms = Stephanocoenia intersepta (Esper) of Vaughan, 1919.

4) S. spongiformis (Duncan, 1864); Figure 1.1.

B. Family Pocilloporidae Gray, 1842: small corallites, simple trabeculae; nonporous coenosteum.

Stylophora Schweigger, 1819: plocoid; septa in two cycles of six; first cycle uniting with styliform columella.

5) $S$. affinis Duncan, 1863. Synonyms = Stylophora panamensis Vaughan, 1919.

6) S. "affinis" of Meeder, 1987.

7) S. granulata Duncan, 1864. Synonyms = Stylophora macdonaldi Vaughan, 1919.

8) S. imperatoris Vaughan, 1919.

9) S. minor Duncan, 1863. Synonyms = Stylophora goethalsi Vaughan, 1919; Stylophora minutissima Vaughan of Weisbord, 1973.

10) S. monticulosa Vaughan in Vaughan and Hoffmeister, 1925; Figure 1.2.

11) S. canalis Vaughan, 1919. Synonyms = Stylocoenia $\mathrm{cf}$. C. pumpellyi (Vaughan) of Weisbord, 1971; Stylophora silicensis Weisbord, 1973.

12) S. undata Weisbord, 1971.

Pocillopora (Lamarck, 1816): plocoid; reduced septa; strong tabular endothecal dissepiments.

13) P. arnoldi Vaughan, 1919

14) P. baracoaensis Vaughan, 1919. 
15) P. crassoramosa Duncan, 1864; Figure 1.3.

16) P. palmata Palmer, 1928.

Madracis Milne Edwards and Haime, 1849a: plocoid to subcerioid; strong septa in cycles of 8 or 10; prominent styliform columella.

17) $M$. decactis (Lyman, 1859).

18) $M$. decaseptata (Weisbord, 1971); Figure 1.4.

19) M. formosa Wells, 1973.

20) M. mirabilis (Duchassaing and Michelotti, 1860).

21) M. pharensis (Heller, 1868).

C. Family Acroporidae Verrill, 1902: small corallites, simple trabeculae; extensive porous, reticulate coenosteum.

Acropora Oken, 1815: ramose with axial corallites; septa in two cycles of six; no columella.

22) A. cervicornis (Lamarck, 1816).

23) A. palmata (Lamarck, 1816).

24) A. panamensis Vaughan, 1919.

25) A. prolifera (Lamarck, 1816).

26) A. saludensis Vaughan, 1919; Figure 1.5. Synonyms = Acropora tampaensis Weisbord, 1973; Acropora sp. 1 of Meeder, 1987.

Astreopora Blainville, 1830: plocoid; extensive porous coenosteum; massive with solid corallite walls; sometimes with columella.

27) A. goethalsi Vaughan, 1919.

D. Family Agariciidae Gray, 1847: corals with confluent septa comprised of closely packed simple trabeculae and united by synapticulae.

Agaricia Lamarck, 1801: unifacial explanate colonies; thickened outer wall; long series; horizontal bars on septocostae.

28) A. fragilis Dana, 1846.

29) A. grahamae Wells, 1973.

30) A. lamarcki Milne Edwards and Haime, 1851.

31) A. sp. A; Figure 1.6.

32) A. undata (Ellis and Solander, 1786).

Undaria Oken, 1815: bifacial or unifacial colonies; thin outer wall; short to long series; randomly oriented septocostal ornamentation.

33) U. agaricites (Linnaeus, 1758).

34) U. crassa (Verrill, 1901); Figure 1.7.

35) U. pusilla (Verrill, 1901).

36) U. sp. A.

Gardineroseris Scheer and Pillai, 1974: mounding or explanate colonies; thin outer wall; short series surrounded by acute collines.

37) G. planulata (Dana, 1846); Figure 1.8.

Pavona Lamarck, 1801: massive or bifacial folia; subcerioid to plocoid; thin outer wall; irregular short series; septal ornament fine or absent.

I. P. (Pseudocolumnastrea) Yabe and Sugiyama, 1933: bifacial folia or rounded branches; plocoid, exsert calices; rare discontinuous collines.

38) $P$. ( $P$.) sp. A; Figure 1.9.

39) $P$. (P.) sp. B.

II. P. (Pavona) s.s.: massive or foliaceous; calical walls often indistinct; collines irregular, radiating or absent.

40) P. (Pavona) panamensis Vaughan, 1919.

41) P. (Pavona) pennyi Vaughan in Vaughan and Hoffmeister, 1926. Synonyms = Pavona machapooriensis Vaughan in Vaughan and Hoffmeister, 1926.

42) P. (Pavona) trinitatis Vaughan in Vaughan and Hoffmeister, 1926.

Helioseris Milne Edwards and Haime, 1849a: unifacial explanate colonies; thickened outer wall; short to long series; open calices; horizontal bars on septocostae; smooth thin septa; weak or absent columella.

43) $H$. cucullata (Ellis and Solander, 1786).

44) $H$. sp. A.

Leptoseris Milne Edwards and Haime, 1849a: unifacial explanate or branched colonies; thickened outer wall; proximally exsert calices; horizontal bars on septocostae.

45) L. anguillensis (Vaughan, 1919).

46) L. cailleti (Duchassaing and Michelotti, 1866).

47) L. gardineri (van der Horst, 1921); Figure 1.10.
48) L. glabra Dinesen, 1980.

49) L. sp. A.

50) L. sp. B.

51) L. walli Vaughan in Vaughan and Hoffmeister, 1926.

E. Family Siderastreidae Vaughan and Wells, 1943: fenestrate septa, synapticulothecal.

Psammocora Dana, 1846: collines present; intratentacular budding; petaloid septal arrangement.

52) P. trinitatis Vaughan in Vaughan and Hoffmeister, 1926; Figure 1.11. Synonyms = Psammocora wyckoffi Hoffmeister in Vaughan and Hoffmeister, 1926.

Siderastrea Blainville, 1830: cerioid; extratentacular budding.

53) S. conferta (Duncan, 1863).

54) $S$. mendenhalli Vaughan, 1917. Synonyms $=S$. californica Vaughan, 1917; S. hillsboroensis Vaughan, 1919.

55) S. pliocenica Vaughan, 1919.

56) S. radians (Pallas, 1766).

57) S. silecensis Vaughan, 1919; Figure 1.12. Synonyms = Sideras trea banksi Weisbord, 1973; Siderastrea dalli Vaughan of Meeder, 1987, and of Weisbord, 1974.

58) S. siderea (Ellis and Solander, 1786).

59) S. stellata Verrill, 1868.

Pironastrea d'Achiardi, 1875: explanate colonies with centers in concentric series formed by circumoral budding.

60) P. anguillensis Vaughan, 1919.

61) P. antiguensis Vaughan, 1919.

F. Family Poritidae Gray, 1842: porous septa, well-defined calices, reduced coenosteum.

Porites Link, 1807: cerioid to subplocoid; two septal cycles; bilateral symmetry.

I. Porites with widely spaced calices and a well-developed wall reticulum.

62) P. anguillensis Vaughan, 1919.

63) $P$. astreoides Lamarck, 1816 [may be $>1 \mathrm{sp}$.]

64) P. macdonaldi Vaughan, 1919; Figure 2.1.

65) $P$. portoricensis (Vaughan, 1919). Synonyms = Goniopora clevei Vaughan, 1919; Porites (Synaraea) howei Vaughan, 1919; Psammocora gasparillensis Vaughan in Vaughan and Hoffmeister, 1926; Goniopora ballistensis Weisbord, 1973; Goniopora matsoni Weisbord, 1973.

66) P. trinitatis Vaughan in Vaughan and Hoffmeister, 1926.

67) P. verrilli Rehberg, 1893.

68) $P$. waylandi Foster, 1986. Synonyms = Porites panamensis Vaughan, 1919; Porites aff. P. astreoides Lamarck of Vaughan and Hoffmeister, 1926; Porites floridaeprima Bernard of Weisbord, 1973.

II. Porites with narrowly spaced calices and a poorly developed wall reticulum.

69) $P$. baracoaensis Vaughan, 1919. Synonyms $=$ Porites douville $i$ Vaughan, 1919; Porites toulai Vaughan, 1919; Porites aff. P. porites (Pallas) of Vaughan and Hoffmeister, 1926.

70) P. branneri Rathbun, 1887.

71) P. carrizensis Vaughan, 1917.

72) P. chipolanum Weisbord, 1971

73) P. colonensis Zlatarski, 1990.

74) P. convivatoris Foster, 1986.

75) $P$. divaricata Lesueur, 1821 [may be $>1 \mathrm{sp}$.]. Synonyms = Porites porites var. divaricata of Geister, 1975.

76) $P$. furcata Lamarck, 1816. Synonyms = Porites porites var. furcata of Geister, 1975.

77) $P$. porites (Pallas, 1766). Synonyms= Porites clavaria Lamarck of Geister, 1975.

Goniopora Blainville, 1830: cerioid to subplocoid; 3 septal cycles; bilateral symmetry.

78) G. calhounensis Weisbord, 1971.

79) G. hilli Vaughan, 1919; Figure 2.2. Synonyms = Goniopora jacobiana Vaughan, 1919; Goniopora tampaensis Weisbord, 1973.

80) G. imperatoris Vaughan, 1919. Synonyms = Goniopora decatu- 
rensis Vaughan of Weisbord, 1973; Goniopora jacobiana Vaughan of Meeder, 1987.

81) G. panamensis Vaughan, 1919.

Alveopora Blainville, 1830: cerioid to subplocoid; rudimentary septa; distinctive thecal pores.

82) A. tampae Weisbord, 1973.

G. Family Faviidae Gregory, 1900: strongly dentate margins and rare synapticulae.

Caulastrea Dana, 1846: phaceloid; mono- to tristomodaeal budding; spongy columella; equal, well-developed costae.

83) C. portoricensis (Coryell in Coryell and Ohlsen, 1929).

Cladocora Ehrenberg, 1834: phaceloid; trabecular columella; septothecal.

84) C. arbuscula (Lesueur, 1821).

85) C. johnsoni Gane, 1895.

86) C. sp. A.

Favia Oken, 1815: massive; plocoid, intratentacular budding; strong costae, not thickened near the wall; trabecular columella; septothecal

87) F. dominicensis Vaughan in Vaughan and Hoffmeister, 1925.

88) $F$. fragum (Esper, 1797).

89) F. gravida Verrill, 1868.

90) F. leptophylla Verrill, 1868.

91) F. sp. A; Figure 2.3.

Goniastrea Milne Edwards and Haime, 1848: massive; meandroid or cerioid; mono- to polycentric corallites arranged in a series; dentate septa; discontinuous columella with paliform lobes.

92) G. canalis Vaughan, 1919. Synonyms = Favites yborensis Weisbord, 1973

Diploria Milne Edwards and Haime, 1848: massive; meandroid; continuous columella, trabecular; single walled, septothecal; no internal lobes; valley width usually $<12 \mathrm{~mm}$.

93) D. bowersi Vaughan, 1917.

94) D. clivosa (Ellis and Solander, 1786).

95) D. labyrinthiformis (Linnaeus, 1758).

96) D. sarasotana Weisbord, 1974.

97) D. strigosa (Dana, 1848).

98) D. sp. A.

99) D. sp. B; Figure 2.4.

Manicina Ehrenberg, 1834: meandroid; continuous, trabecular columella; single walled (sometimes double walled), septothecal; internal lobes; valley width usually $>12 \mathrm{~mm}$.

I. Mancina s.s.: branched series.

100) $M$. areolata (Linnaeus, 1758).

101) M. mayori Wells, 1936.

102) $M$. puntagordensis Weisbord, 1968; Figure 2.5. Synonyms = Manicina cf. M. gyrosa (Ellis and Solander) of Weisbord, 1974; Manicina areolata forma mayori of Meeder, 1987.

II. Teleiophyllia Duncan, 1864: unbranched series; freeliving.

103) $M$. (T.) grandis (Duncan, 1864).

104) $M .(T$.$) navicula (Duncan, 1864).$

105) $M .(T$.$) sp. A.$

106) $M$. (T.) sp. B; Figure 2.6 .

107) $M .(T$.$) sp. C.$

108) $M .(T$.$) sp. D.$

Thysanus Duncan, 1863: unidirectional branched and unbranched series; continuous, trabecular columella; septothecal; freeliving.

109) T. crassicostatus Vaughan in Vaughan and Hoffmeister, 1925.

110) T. excentricus Duncan, 1863; Figure 2.7. Synonyms = Thysanus hayesi Vaughan, 1919; Thysanus vaughani Weisbord, 1971.

111) T. floridanus Weisbord, 1974.

Colpophyllia Milne Edwards and Haime, 1848: massive; meandroid; discontinuous columella with lamellar linkage; commonly double walled, parathecal: valley width usually $>15-20 \mathrm{~mm}$.

112) C. amaranthus (Müller, 1775).

113) C. breviserialis Milne Edwards and Haime, 1849a.

114) C. natans (Müller, 1775); Figure 2.8.
Antiguastrea Vaughan, 1919: massive, plocoid; extratentacular budding; weak costae; lamellar columella; septothecal.

115) A. cellulosa (Duncan, 1863). Synonyms = Antiguastrea cf. $A$. cellulosa silicensis Vaughan of Weisbord, 1971.

Montastraea Blainville, 1830: plocoid, extratentacular budding; strong costae, not thickened near the wall; trabecular columella; septothecal; massive.

I. Montastraea with approx. 24 septa.

116) M. annularis (Ellis and Solander, 1786) morph 1 of Knowlton et al., 1992.

117) $M$. annularis (Ellis and Solander, 1786) morph 2 of Knowlton et al., 1992. Synonyms = Montastrea annularis (Ellis and Solander) of Meeder, 1987, of Geister, 1982, of Weisbord, 1974, and of Geister, 1975.

118) M. annularis (Ellis and Solander, 1786) morph 3 of Knowlton et al., 1992.

119) $M$. brevis (Duncan, 1864).

120) $M$. imperatoris $($ Vaughan, 1919). Synonyms = Montastrea annularis (Ellis and Solander) of Weisbord, 1973.

121) M. limbata (Duncan, 1863); Figure 2.9.

122) $M$. sp. A.

123) M. trinitatis (Vaughan in Vaughan and Hoffmeister, 1926). Synonyms = Orbicella cumutensis Hoffmeister in Vaughan and Hoffmeister, 1926; Orbicella altissima (Duncan) of Vaughan and Hoffmeister, 1926.

II. Montastraea with $\gg 24$ septa.

124) $M$. canalis (Vaughan, 1919). Synonyms = Montastrea $\mathrm{cf} . M$. costata (Duncan) of Weisbord, 1971; Montastrea tampaensis silecensis (Vaughan) of Weisbord, 1973.

125) M. cavernosa (Linnaeus, 1767) morph 1 of Budd, 1993.

126) $M$. cavernosa (Linnaeus, 1767) morph 2 of Budd, 1993.

127) $M$. cavernosa (Linnaeus, 1767) morph 3 of Budd, 1993.

128) $M$. cylindrica (Duncan, 1863); Figure 2.10.

129) $M$. endothecata (Duncan, 1863). Synonyms = Montastrea cavernosa (Linnaeus) of Weisbord, 1971.

130) M. tampaensis (Vaughan, 1919).

Solenastrea Milne Edwards and Haime, 1848: massive; plocoid; extratentacular budding; extremely weak costae; trabecular columella with reduced paliform lobes; septothecal.

131) S. bournoni Milne Edwards and Haime, 1849a; Figure 2.11. Synonyms = Cyphastrea tampae Weisbord, 1973.

132) S. fairbanksi (Vaughan, 1900).

133) S. hyades (Dana, 1846). Synonyms = Montastrea davisina Weisbord, 1973; Montastrea peninsularis Weisbord, 1973.

Agathiphyllia Reuss, 1864: massive; plocoid; extratentacular budding; strong costae; trabecular collumella with strong paliform lobes; synapticulothecal.

134) A. hilli (Vaughan, 1919).

H. Family Trachyphylliidae Verrill, 1901: dentate septa, inner fan of trabeculae forming prominent lobes.

Trachyphyllia Milne Edwards and Haime, 1848: flabello-meandroid, polycentric.

135) $T$. bilobata (Duncan, 1863); Figure 2.12. Synonyms = Antillia bullbrooki Hoffmeister in Vaughan and Hoffmeister, 1926; Antillophyllia chipolana Weisbord, 1971; Antillia willcoxi (Dana) Vaughan of Weisbord, 1973; Trachyphyllia sp. 2 of Meeder, 1987; Antillia sp. 3 of Meeder, 1987; Scolymia sp. 4 of Meeder, 1987.

136) T. sp. A.

Antillophyllia Vaughan, 1932: solitary, monocentric.

137) A. sawkinsi (Vaughan in Vaughan and Hoffmeister, 1926).

I. Family Meandrinidae Gray, 1847: fine septal dentations, lamellar columella, solid coenosteum, invariably intratentacular budding.

Meandrina Lamarck, 1801: meandroid, intratentacular budding; lamellar septa; discontinuous columella.

I. Meandrina s.s.: species with more than one valley.

138) $M$. braziliensis (Milne Edwards and Haime, 1849a); Figure 3.1.

139) $M$. meandrites (Linnaeus, 1767). 
II. Placocyathus Milne Edwards and Haime, 1848: species with only one valley; freeliving.

140) $M .(P$.$) alveolus Duncan, 1863$.

141) $M .(P$.$) barretti Duncan, 1863$.

142) $M$. (P.) costatus Duncan, 1864; Figure 3.2.

143) $M$. (P.) trinitatis Vaughan in Vaughan and Hoffmeister, 1926.

144) $M .(P$.$) variabilis Duncan, 1864$.

Dichocoenia Milne Edwards and Haime, 1848: polystomodaeal to meandroid; intratentacular budding; heavy, granular coenosteum; welldeveloped, trabecular columella.

145) D. caloosahatcheensis Weisbord, 1974.

146) D. eminens Weisbord, 1974.

147) D. merriami (Vaughan, 1900).

148) D. stokesi Milne Edwards and Haime, 1848.

149) D. stellaris Milne Edwards and Haime, 1849a.

150) D. tuberosa Duncan, 1863; Figure 3.3.

Dendrogyra Ehrenberg, 1834: meandroid with long corallite series; intratentacullar budding; columella composed of discontinuous lamella. 151) D. cylindricus Ehrenberg, 1834.

J. Family Oculinidae Gray, 1847: fine septal dentations, vesicular or solid coenosteum, extratentacular budding (only massive, exclusively hermatypic taxa included).

Galaxea Oken, 1815: massive, plocoid, no columella.

152) G. excelsa Weisbord, 1973; Figure 3.4.

K. Family Mussidae Ortmann, 1890: solitary or colonial with large coarse septal dentition.

Antillia Duncan, 1863: solitary, free living; septothecate with epitheca; regular large rounded septal dentition.

153) A. dentata Duncan, 1864; Figure 3.5.

154) A. gregorii Vaughan, 1901. Synonyms = Syzygophyllia tampae Weisbord, 1973.

Scolymia Haime, 1852: solitary, attached; parathecate, no epitheca; irregular attenuate or triangular septal dentition.

155) S. cubensis (Milne Edwards and Haime, 1849b).

156) S. wellsi (Laborel, 1967).

157) S. lacera (Pallas, 1766).

Mussa Oken, 1815: branched phaceloid; septothecate; no epitheca; irregular thin teeth.

158) M. angulosa (Pallas, 1766).

Mussismilia Ortmann, 1890: branched phaceloid or plocoid, parathecate, small regular septal dentition.

159) $M$. braziliensis (Verrill, 1868).

160) M. harttii (Verrill, 1868).

161) M. hispida (Verrill, 1901).

Isophyllia Milne Edwards and Haime, 1851: massive; parathecate; discontinuous series; trabecular linkage between centers; irregular thin teeth.

162) I. sp. A.

163) I. sinuosa (Ellis and Solander, 1786).

Isophyllastrea Matthai, 1928: massive; parathecate; mono- to tricentric calices; coarse or thin septal dentition; weak or absent columella.

164) I. sp. A.

165) I. rigida (Dana, 1848).

Mycetophyllia Milne Edwards and Haime, 1848: massive or plate shaped; calices in series with lamellar linkage between centers; irregular thin to coarse septal dentition.

166) M. aliciae Wells, 1973

167) M. bullbrooki Vaughan in Vaughan and Hoffmeister, 1926.

168) $M$. danaana Milne Edwards and Haime, 1849a.

169) M. ferox Wells, 1973.

170) M. lamarckiana Milne Edwards and Haime, 1848.

171) M. reesi Wells, 1973.

L. Family Caryophylliidae Gray, 1847: costae covered by epitheca; exsert, subequal septa.

Eusmilia Milne Edwards and Haime, 1848: phaceloid; mono- to tristomodaeal budding; reduced columella.
172) E. carrizensis Vaughan, 1917.

173) E. fastigiata (Pallas, 1766).

174) E. flabellata Wells, 1973.

175) E. sp. A; Figure 3.6.

\section{SYSTEMATIC BIBLIOGRAPHY}

AChiARDI, A. D'. 1875. Coralli eocenici del Friuli. Societa Toscana di Scienze Naturelle, Pisa, Atti, Proc. Verb., 2:239-242.

Blainville, H. M. DE. 1830 . Dictionnaire des sciences naturelles. Zoophytes, Volume 60, Paris, p. 297-364.

BUDD, A. F. 1993. Variation within and among morphospecies of Montastraea. Courier Forschungs-Institut Senckenberg, 164:241-254.

Coryell, H. N., AND V. OHLSEN. 1929. Fossil corals of Porto Rico, with descriptions also of a few Recent species. New York Academy of Sciences, Scientific Survey of Porto Rico and the Virgin Islands, 3:167-236.

DANA, J. D. 1846. Zoophytes. United States Exploring Expedition 1838-1842, Philadelphia, Volume 7, 1-120, 709-720.

. 1848. Zoophytes. United States Exploring Expedition 18381842, Philadelphia, Volume 7, 121-708, 721-740.

DINESEN, Z. D. 1980. A revision of the coral genus Leptoseris (Scleractinia: Fungiina: Agariciidae). Memoirs of the Queensland Museum, 20:181-235.

Duchassaing, P., AND J. Michelotti. 1860. Mémoire sur les coralliaires des Antilles. Memorie della Reale Accademia delle Scienze di Torino. Serie Seconda, 19:56-87.

— AND - . 1866. Supplemént au mémoire sur les coralliaires des Antilles. Memorie della Reale Accademia delle Scienze di Torino. Serie Seconda, 23:97-206.

DunCAN, P. M. 1863. On the fossil corals of the West Indian Islands. Part 1. Quarterly Journal of the Geological Society of London, 19: 406-458.

1864. On the fossil corals of the West Indian Islands. Part 2. Quarterly Journal of the Geological Society of London, 20:20-44.

1873. On the older Tertiary formations of the West Indian Islands. Quarterly Journal of the Geological Society of London, 29: 548-565.

EHRENBERG, G. G. 1834. Beiträge zur physiologischen Kenntniss der Corallenthiere im allgemeinen und besonders des Rothen Meeres. Kaiserliche Akademie der Wissenschaften Berlin, Abhandlungen, 1832: 250-380.

ELLIS, J., AND D. SolANDER. 1786. The natural history of many curious and uncommon zoophytes. London, $208 \mathrm{p}$.

ESPER, J. C. 1797. Fortsetzungen der Pflanzenthiere. Nürnberg, 1:169230.

FOSTER, A. B. 1986. Neogene paleontology in the northern Dominican Republic. 3. The family Poritidae (Anthozoa: Scleractinia). Bulletins of American Paleontology, 90:47-123.

. 1987. Neogene paleontology in the northern Dominican Republic. 4. The genus Stephanocoenia (Anthozoa: Scleractinia: Astrocoeniidae). Bulletins of American Paleontology, 93:5-22.

GANE, H. S. 1895. A contribution to the Neocene corals of the United States. Johns Hopkins University Circular, 15:8-10.

GEISTER, J. 1975. Riffbau und geologische Entwicklungsgeschichte der Insel San Andrés (westliches Karibisches Meer, Kolumbien). Stuttgarter Beiträge zur Naturkunde, B, 15, 203 p.

. 1982. Pleistocene reef terraces and coral environments at Santo Domingo and near Boca Chica, southern coast of the Dominican Republic. North Caribbean Geological Conference (Santo Domingo, 1980), Transactions, 2:689-703.

GRAY, J. E. 1842. Northern Zoological Gallery, Room II, III, Radiated animals, p. 128-135. In Synopsis of the Contents of the British Museum, 44th edition. London.

- 1847. An outline of an arrangement of stony corals. Annals and Magazine of Natural History, Series 1, 19:120-128.

Gregory, J. W. 1900. The corals. Jurassic fauna of Cutch. Palaeontologica Indica, Series 9, 2:1-195.

HAIme, J. 1852. In Bellardi, Catalogue raisonné des fossiles nummulitiques du Comté de Nice. Société de la Géologique France, Mémoires, 4:279-290.

Heller, C. 1868. Die Zoophyten und Echinodermen des Adriatischen Meeres. Zoologische Botanische Verhandlungen Wien, 18:1-88. 
Horst, C. J. vAN DER. 1921. The Madreporaria of the Siboga Expedition. II. Madreporaria Fungida. Siboga Expeditie, XVI b:53-98.

Knowlton, N., E. Wein, L. A. Weigt, and H. M. Guzman. 1992. Sibling species in Montastraea annularis, coral bleaching, and the coral climate record. Science, 255:330-333.

KoBY, F. 1890. Monographie des polypiers jurassiques de la Suisse. Société de la Paléontologie Suisse, Mémoires, 16:467-582.

LABOREL, J. 1967. A revised list of Brazilian scleractinian corals and description of a new species. Postilla, 107, $14 \mathrm{p}$.

LamarCK, J. B. P. 1801. Système des animaux sans vertèbres. Paris, $432 \mathrm{p}$.

- 1816. Histoire naturelle des animaux sans vertèbres, Volume 2. Paris, $568 \mathrm{p}$.

LESUEUR, C. A. 1821. Déscription de plusieurs animaux appartenant aux polypiers lamellifêres de $M$. le Chev. de Lamarck. Mémoires du Muséum d'Histoire naturelle, 6:271-298.

LiNK, H. F. 1807. Beschreibung der Naturalien-Sammlungen der Universität Rostock, 3:161-165.

LiNNAEUS, C. 1758. Systema Naturae per regnia tria naturae, secundum Classes, Ordines, Genera, Species. Tomus I. Regnum Animale. Holmiae, Editio Decima, Reformata, 824 p.

- 1767. Madrepora. Systema Naturae. Holmiae, Editio Duodecima, Reformata, Pt. 2, t. 1, 1272-1282.

Lyman, T. 1859. On a new species of coral (Astraea decactis). Proceedings of the Boston Society of Natural History, 6:260-263.

MatthaI, G. 1928. A monograph of the recent meandroid Astraeidae. Catalogue of the Madreporarian corals in the British Museum (Natural History), 7:1-288.

Meeder, J. F. 1987. The paleoecology, petrology and depositional model of the Pliocene Tamiami Formation, southwest Florida (with special reference to corals and reef development). Unpubl. Ph.D. dissertation, University of Miami, Coral Gables, Florida, 748 p.

Milne Edwards, H., AND J. Haime. 1848. Recherches sur les polypiers. Quatrième mémoire. Monographie des Astréides. Annales des Sciences Naturelles, Paris, Series 3, 10:209-320.

—, AND - 1849a. Mémoire sur les polypiers appartenant à la famille des Oculinides, au groupe intermédiaire des Pseudastréides et à la famille des Fongides (extrait). Academie de la Science, Paris, C. R., 29:67-73.

—, AND — . 1849b. Recherches sur les polypiers. Quatrième mémoire. Monographie des Astréides. Annales des Sciences Naturelles, Paris, Series 3, 12:95-197.

- AND - 1851. Recherches sur les polypiers. 6me Mémoire. Monographie des Fongides. Annales des Sciences Naturelles, Paris, Series 3, 15:73-144.

MülleR, P. L. S. 1775. Des Ritters Carl von Linné Königlich Schwedischen Leibarztes vollständiges Natursystem nach der zwölften lateinischen Ausgabe mit einer ausführlichen Erklärung. Sechster Theil, Zweiter Band, Von den Korallen. Nürnberg, p. 672-708.

OKEN, L. 1815. Lehrbuch der Naturgeschichte. Jena, Theil 3, Zoologie. Abteilung I, Fleischlose Thiere, $850 \mathrm{p}$.

OrtmanN, A. 1890. Die morphologie des Skeletts der Steinkorallen in Beziehung zur Koloniebildung. Zeitschrift für wissenschaftliches Zoologie, Leipzig, 50:278-316.

Pallas, P. S. 1766. Elenchus Zoophytorum. Hagae-Comitum, 451 p.

PALMER, R. H. 1928. Fossil and Recent corals and coral reefs of western Mexico. American Philosophical Society Proceedings, 68:2131.

Rathbun, R. 1887. Annotated catalogue of the species of Porites and Synaraea in the U.S. National Museum, with a description of a new species of Porites. Proceedings of the U.S. National Museum, 10:354 366.

REHBERG, H. 1893. Neue und wenig bekannte Korallen. Abhandlungen der Naturwissenschaften Verein, Hamburg, 12:1-50.
Reuss, A. E. 1864. Die fossilen Foraminiferen, Anthozoen und Bryozoen von Oberberg in Steiermark. Kaiserliche Akademie der Wissenschaft Wien, mathematisch-naturwissenschaftliche Klasse, Denkschriften $23,38 \mathrm{p}$.

Scheer, G., AND C. S. G. Pillai. 1974. Report on Scleractinia from the Nicobar Islands. Zoologica (Stuttgart), 42:1-75.

SCHWEIGGER, A. F. 1819. Beobachtungen auf naturhistorischen Reisen. Anatomische-physiologische Untersuchungen über Corallen; nebst ein Anhange, Bemerkungen über die Bernstein enthaltend, Berlin, $127 \mathrm{p}$.

VAughan, T. W. 1900. The Eocene and lower Oligocene coral faunas of the United states with descriptions of a few doubtfully Cretaceous species. U.S. Geological Survey, Monograph 39, 263 p.

- 1901. Some fossil corals from the elevated reefs of Curacao, Aruba and Bonaire. Rijks Geologisches Mineralogisches Museum Sammlungen, Leiden, 2:1-91.

- 1917. The reef-coral fauna of Carrizo Creek, Imperial County, California and its significance. U.S. Geological Survey, Professional Paper 98T:355-386.

1919. Fossil corals from Central America, Cuba, and Porto Rico with an account of the American Tertiary, Pleistocene, and Recent coral reefs. U.S. National Museum Bulletin, 103:189-524.

- 1932. Antillophyllia, a new coral generic name. Journal of the Washington Academy of Science, 22:506-510.

- AND J. E. HoffMeister. 1925. New species of fossil corals from the Dominican Republic. Bulletin of the Museum of Comparative Zoology, Harvard College, 67:315-326.

, AND - 1926. Miocene corals from Trinidad. Papers of the Department of Marine Biology, Carnegie Institution of Washington, 23:107-132.

-, AND J. W. Wells. 1943. Revision of the suborders, families, and genera of the Scleractinia. Geological Society of America, Special Paper 104, $363 \mathrm{p}$.

VERRILL, A. E. 1868. Notice of the corals and echinoderms collected by Prof. C. F. Hartt, at the Abrolhos Reefs, Province of Bahia, Brazil, 1867. Connecticut Academy of Arts and Science, Transactions, 1:351359.

- 1901. Variations and nomenclature of Bermudian, West Indian, and Brazilian reef corals, with notes on various Indo-Pacific corals. Connecticut Academy of Arts and Sciences, Transactions, 11:63-168. . 1902. Notes on corals of the genus Acropora Madrepora (Lam.) with new descriptions and figures of types and several new species. Connecticut Academy of Arts and Science, Transactions, 11:207-266.

WEISBORD, N. E. 1968. Some late Cenozoic stony corals from northern Venezuela. Bulletins of American Paleontology, 55:1-288.

- 1971. Corals from the Chipola and Jackson Bluff Formations of Florida. Florida Bureau of Geology, Geological Bulletin, 53, 100 p.

1973. New and little-known corals from the Tampa Formation of Florida; Florida Bureau of Geology, Geological Bulletin, 56, $147 \mathrm{p}$. - 1974. Late Cenozoic corals of South Florida. Bulletins of American Paleontology, 66:259-543.

WELLS, J. W. 1936. The nomenclature and type species of some genera of recent and fossil corals. American Journal of Science, Series 5, 31 97-134.

- 1973. New and old scleractinian corals from Jamaica. Bulletin of Marine Science, 23:16-55.

- AND J. C. LANG. 1973. Systematic list of Jamaican shallow-water Scleractinia. Bulletin of Marine Science, 23:55-58.

YABE, H., AND T. Sugryama. 1933. Notes on three new corals from Japan. Japanese Journal of Geology and Geography, 11:11-18.

Zlatarski, V. 1990. Porites colonensis, new species of stony coral (Anthozoa: Scleractinia) off the Caribbean coast of Panama. Proceedings of the Biological Society of Washington, 103:257-264. 